\title{
Design of bio-based supramolecular structures through self-assembly of $\alpha$-lactalbumin and lysozyme
}

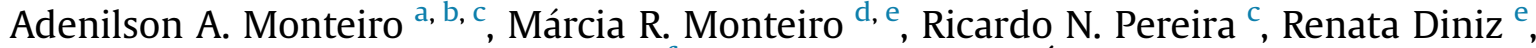

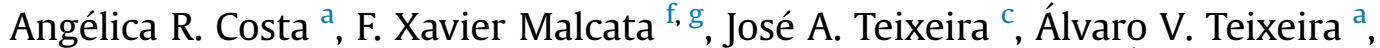 \\ Eduardo B. Oliveira ${ }^{a}$, Jane S. Coimbra ${ }^{\text {a, e}}$, António A. Vicente ${ }^{c}$, Óscar L. Ramos ${ }^{\text {c, f, * }}$ \\ a Department of Food Technology, Universidade Federal de Viçosa, Viçosa, Minas Gerais, Brazil \\ ${ }^{\mathrm{b}}$ COLUNI - Colégio de Aplicação da Universidade Federal de Viçosa, Viçosa, Brazil \\ c CEB - Centre of Biological Engineering, University of Minho, 4710-057 Braga, Portugal \\ d Department of Nutrition, School of Nursing, Universidade Federal de Minas Gerais, Belo Horizonte, Brazil \\ e UFPA - Universidade Federal do Pará, Belém, Pará, Brazil \\ ${ }^{\mathrm{f}}$ LEPABE - Laboratório de Engenharia de Processos, Ambiente, Biotecnologia e Energia, University of Porto, Porto, Portugal \\ $\mathrm{g}$ Department of Chemical Engineering, University of Porto, Porto, Portugal
}

\section{A R T I C L E I N F O}

\section{Article history:}

Received 17 August 2015

Received in revised form

4 February 2016

Accepted 8 February 2016

Available online 12 February 2016

\section{Keywords:}

Globular proteins

Food-grade structures

Assembly mechanism

Electrostatic interactions

Thermal treatment

Food application

\begin{abstract}
A B S T R A C T
Bovine $\alpha$-lactalbumin ( $\alpha$-La) and lysozyme (Lys), two globular proteins with highly homologous tertiary structures and opposite isoelectric points, were used to produce bio-based supramolecular structures under various $\mathrm{pH}$ values $(3,7$ and 11$)$, temperatures $\left(25,50\right.$ and $\left.75{ }^{\circ} \mathrm{C}\right)$ and times $(15,25$ and $35 \mathrm{~min})$ of heating. Isothermal titration calorimetry experiments showed protein interactions and demonstrated that structures were obtained from the mixture of $\alpha$-La/Lys in molar ratio of 0.546 . Structures were characterized in terms of morphology by transmission electron microscopy (TEM) and dynamic light scattering (DLS), conformational structure by circular dichroism and intrinsic fluorescence spectroscopy and stability by DLS. Results have shown that protein conformational structure and intermolecular interactions are controlled by the physicochemical conditions applied. The increase of heating temperature led to a significant decrease in size and polydispersity (PDI) of $\alpha$-La-Lys supramolecular structures, while the increase of heating time, particularly at temperatures above $50^{\circ} \mathrm{C}$, promoted a significant increase in size and PDI. At pH 7 supramolecular structures were obtained at microscale - confirmed by optical microscopy - displaying also a high PDI (i.e. > 0.4). The minimum size and PDI $(61 \pm 2.3 \mathrm{~nm}$ and $0.14 \pm 0.03$, respectively) were produced at $\mathrm{pH} 11$ for a heating treatment of $75{ }^{\circ} \mathrm{C}$ for $15 \mathrm{~min}$, thus suggesting that these conditions could be considered as critical for supramolecular structure formation. Its size and morphology were confirmed by TEM showing a well-defined spherical form. Structures at these conditions showed to be stable at least for 30 or 90 days, when stored at 25 or $4{ }^{\circ} \mathrm{C}$, respectively. Hence, $\alpha$-La-Lys supramolecular structures showed properties that indicate that they are a promising delivery system for food and pharmaceutical applications.
\end{abstract}

() 2016 Elsevier Ltd. All rights reserved.

\section{Introduction}

Milk proteins, and whey proteins in particular are widely used as ingredients in formulated foods because they are valuable byproducts, generally recognized as safe (GRAS), and have high nutritional value - due to their high content of essential amino

\footnotetext{
* Corresponding author. CEB - Centre of Biological Engineering, University of Minho, 4710-057 Braga, Portugal.

E-mail address: os.silva.ramos@gmail.com (Ó.L. Ramos).
}

acids especially sulfur-containing ones (de Wit, 1998; Ramos, Fernandes, Silva, Pintado, \& Malcata, 2012a). Moreover, these proteins have important biological physical and chemical functionalities essential in food applications (Dickinson, 2003; Dissanayake \& Vasiljevic, 2009; Gunasekaran, Ko, \& Xiao, 2007; Madureira, Pereira, Gomes, Pintado, \& Malcata, 2007; Sarkar, Goh, Singh, \& Singh, 2009).

$\alpha$-Lactalbumin ( $\alpha$-La) is quantitatively the second most important protein in whey - representing ca. $20 \%(\mathrm{w} / \mathrm{w}$ ) of the total whey proteins. It has as relevant characteristic, the strong tendency to 
form associations with other proteins at $\mathrm{pH}$ below its isoelectric point (i.e. $\mathrm{pI}=4.8$ ) (Sgarbieri, 2005b). Lysozyme (Lys) presents a three-dimensional structure homologous to that of $\alpha$-La, including a similar sequence of amino acid residues and four disulfide bonds (McKenzie \& White, 1991; Qasba, Kumar, \& Brew, 1997). These globular proteins present particular interest once can interact via electrostatic bonds and assembly into supramolecular structures (Iyer \& Qasba, 1999; Nigen, Le Tilly, Croguennec, Drouin-Kucma, \& Bouhallab, 2009b).

Supramolecular structures are stable and well-defined chemical systems formed by molecules, such as proteins, held together by weak intermolecular interactions (e.g. hydrogen bonding, electrostatic interactions and Van der Waals interactions) (Lehn, 2007). Depending on the balance of interactions (protein conformation) and on physicochemical conditions of the medium, different structures such as aggregates, spherulites, fibrils and tubes can be formed at micro- and nanoscale (Goers, Permyakov, Permyakov, Uversky, \& Fink, 2002; Ipsen, Otte, \& Qvist, 2001; Nigen, Croguennec, Renard, \& Bouhallab, 2007).

Therefore, understanding the driving forces that trigger protein self-assembly and the sequential steps leading to the building of supramolecular structures is of high importance for controlling their shape, size and properties. For instance, most studies in this field have focused on monoprotein systems, particularly towards elucidation of fibrillation mechanism of proteins or peptides (Krebs, Bromley, Rogers, \& Donald, 2005; Leonil et al., 2008). Understanding the mechanisms of protein assembly in more complex systems, involving more than one protein is of major interest for the design of new protein assemblies with specific or innovative functionalities (Augustin \& Hemar, 2009; Nigen, Gaillard, Croguennec, Madec, \& Bouhallab, 2010; Sanguansri \& Augustin, 2006; Shuguang, 2003; Viney, 2004). In addition, studying the behavior of the supramolecular structure formed by different proteins can also help controlling the final quality of different industrial foodstuffs (Erabit, Flick, \& Alvarez, 2014).

One of the most recent functionalities attributed to structures made from self-assembly of proteins is their use as carriers for controlled release of bioactive compounds in food products (Augustin \& Oliver, 2012; Israeli-Lev \& Livney, 2014). Since carriers at nanoscale are sub-cellular in size, they have versatile advantages for targeted, site-specific delivery purposes as long as they can penetrate circulating systems and reach specific sites in the body (Vinogradov, Bronich, \& Kabanov, 2002), thus being of high interest for application in the food and pharmaceutical industries (Cerqueira et al., 2014; Ramos et al., 2015).

The information available on development of bio-based supramolecular structures by self-assembly of globular proteins is scarce (Diniz et al., 2014) and (Nigen et al., 2009a; Nigen et al., 2007; Nigen et al., 2010; Nigen, Le Tilly, et al., 2009b). The former authors reported self-assembly of $\alpha$-La and glycomacropeptide (GMP) whey proteins into supramolecular structures, under varying heat treatments $\left(25-75{ }^{\circ} \mathrm{C}\right)$ and $\mathrm{pH}$ conditions ( $\mathrm{pH} 3.5$ to 6.5); while the latter authors demonstrated the self-assembly of apo $\alpha$-La and hen egg white Lys into spherical supramolecular particles, at both macro- and microscopic level (i.e. from 2 to $4 \mu \mathrm{m}$ in diameter) in a temperature-dependent manner. However, none of these studies discusses the molecular behavior of the structures at nanoscale level, or the effect of combined environmental conditions (i.e. various $\mathrm{pH}$ values, temperature of heating and holding times) upon protein assembly during supramolecular structure formation. The properties at nanoscale can be quite different from macro- or micro-sized structures manufactured from the same proteins (Kaya-Celiker \& Mallikarjunan, 2012). Understanding protein-protein interactions and their mechanisms of assembly will permit control of the hierarchical building of well-ordered supramolecular structures - a highly relevant deed for tailor-made new biomaterials (Sanguansri \& Augustin, 2006). Therefore, the aim of the present study was to shed light on the effect of combined conditions (various $\mathrm{pH}$ values, temperatures and heating times) on development of bio-based supramolecular structures at nanoscale through self-assembling of $\alpha$-La and Lys. The effect of the different experimental conditions on the conformation of the new structures, the role of non-covalent interactions in supramolecular structures' formation and stabilization, as well as their morphology and stability during 5 months of storage at different temperatures were also ascertained.

\section{Materials and methods}

\subsection{Materials}

$\alpha$-Lactalbumin ( $\alpha$-La) (lot JE 002-1-410), was kindly supplied by Davisco Foods International, Inc. (Le Sueur, MN, USA), whereas lysozyme (Lys) from chicken egg white was purchased from Sigma-Aldrich (activity 70,000 U/mg, Belgium). Both proteins were obtained as a lyophilized powder and used without further purification. Ultrapure water (with a resistivity of $18.2 \mathrm{M} \Omega \mathrm{cm}$ ) used to prepare the protein dispersions, was obtained with a Milli-Q Ultrapure water purification system (Millipore, Bedford MA, USA). $\mathrm{NaOH}\left(1 \mathrm{~mol} \mathrm{~L}^{-1}\right)$ and $\mathrm{HCl}\left(1 \mathrm{~mol} \mathrm{~L}^{-1}\right)$ used for $\mathrm{pH}$ adjustment of protein dispersions, whereas sodium azide $\left(\mathrm{NaN}_{3}\right)$ used as preservative, were of analytical grade (Merck, Darmstadt, Germany). All other chemicals were reagent-grade or higher, and were used without further purification.

\subsection{Preparation of $\alpha$-La and Lys solutions}

Stock solutions of $\alpha$-La and Lys were prepared by dissolving $2 \mathrm{mg} \mathrm{mL}{ }^{-1}$ of each protein powder in ultrapure water. Both solutions were then stirred continuously (300 rpm) using a magnetic stirrer (IKA ${ }^{\mathbb{B}} \mathrm{R}-10$, Germany), for $30 \mathrm{~min}$ at room temperature (ca. $25{ }^{\circ} \mathrm{C}$ ), to ensure protein rehydration. The assays (differential scanning calorimetry and isothermal titration calorimetry) were always carried out at the $\mathrm{pH}$ of native proteins in solution (i.e. 7.3 and 4.3 for $\alpha$-La and Lys, respectively). These conditions had been optimized previously (Monteiro, 2014).

\subsection{Differential scanning calorimetry}

The thermal behavior of $\alpha$-La and Lys proteins was assessed by differential scanning calorimetry (DSC) using a MicroCal VP-DSC calorimeter (MicroCal, England), equipped with VP Viewer 2000 - Origin 7 thermal analysis system software. The instrument was calibrated with an indium standard $\left(T_{\mathrm{m}}=156.6{ }^{\circ} \mathrm{C}\right.$ and $\left.\Delta H_{\mathrm{m}}=28.71 \mathrm{~J} \mathrm{~g}^{-1}\right)$ and deionised water $\left(T_{\mathrm{m}}=0{ }^{\circ} \mathrm{C}\right.$ and $\Delta \mathrm{H}_{\mathrm{m}}=333 \mathrm{~J} \mathrm{~g}^{-1}$ ) as standards. The calibration procedure was completed with the scanning rate to be used in the trials. The samples (aliquots of $500 \mu \mathrm{L}$ ) were weighed directly in hermetically sealed aluminium pans (Al crimp Pan C.201-52090) with an automatic electro-balance AE 200 (from Mettler, Columbus OH, USA), with a precision of $\pm 0.01 \mathrm{mg}$; an empty pan was used as reference. Nitrogen was used as carrier at a flow rate of $20 \mathrm{~mL} \mathrm{~min}^{-1}$. Samples were equilibrated at $20^{\circ} \mathrm{C}$ for $5 \mathrm{~min}$, and measurements were then performed between 20 and $100{ }^{\circ} \mathrm{C}$ at a heating rate of $1^{\circ} \mathrm{C} \mathrm{min}-1$. These conditions were selected based in previous studies carried out by Monteiro (2014).

Thermal transitions were evaluated in terms of melting temperature $\left(T_{m}\right.$, i.e. the temperature of the peak maximum), and melting enthalpy $(\Delta \mathrm{H})$. At least three replicates were tested. This technique was employed because it is considered one of the most 
useful to determine thermal stability of proteins and to measure the thermodynamic parameters of thermal protein unfolding (Gill, Moghadam, \& Ranjbar, 2010).

\subsection{Isothermal titration calorimetry}

The interactions between $\alpha$-La and Lys were investigated by determining the changes in enthalpy of association of these proteins. Experiments were performed using isothermal titration calorimeter (ITC), VP-ITC (Microcal Inc., England), in multiple injection mode, at $25^{\circ} \mathrm{C}$. The resulting data were then analyzed using Microcal's ITC data analysis package, VP Viewer 2000, which uses the scientific plotting software, Origin 7 (Origin Lab. Corp., MA, USA). In these experiments, a stainless steel cell filled with $2 \mathrm{~mL}$ of Lys aqueous solution $\left(71 \mu \mathrm{mol} \mathrm{L}^{-1}\right)$ was titrated with $\alpha$-La aqueous solution $\left(710 \mu \mathrm{mol} \mathrm{L}^{-1}\right)$. This titration was carried out by sequential injections of $300 \mu \mathrm{L}$ of $\alpha$-La titrant solution at $300 \mathrm{~s}$ intervals for a total of 25 injections. These conditions were chosen based in previous studies carried out elsewhere (Monteiro, 2014). Furthermore, $\alpha$-La was titrated in water, and these results were subtracted from the protein titration data. A mathematical model was used to perform a non-linear fit to corrected heat data, thus producing a titration curve allowing determination of the stoichiometric coefficient $(N)$, the equilibrium constant $(K)$, the standard enthalpy change of interaction $\left(\Delta H^{\circ}\right)$, the standard Gibbs free energy of interaction $\left(\Delta G^{\circ}\right)$ - through equation (1), and the standard entropic change $\left(\Delta S^{\circ}\right)-$ through equation (2).

$\Delta G^{\circ}=-R T \ln K_{a}$

$\Delta G^{\circ}=\Delta H^{\circ}-T \Delta S^{\circ}$

\subsection{Experimental design}

The Box-Behnken experimental design was used to optimize and evaluate the effects of $\mathrm{pH}\left(X_{1}\right)$, heating temperature $\left(X_{2}\right)$ and time $\left(X_{3}\right)$ - independent variables, upon the particle size $\left(Y_{1}\right)$ and polydispersity index - PDI $\left(Y_{2}\right)$ - dependent variables, towards development of protein supramolecular structures. A 3-factor, 3level design was used because it was the most appropriated for exploring quadratic response surfaces and constructing second order polynomial models for optimization. The independent variables and levels (i.e. low, medium and high) used in this design are listed in Table 1 and were selected based on the results from the preliminary experiments. For the said design, a total of 15 experiments were performed.

\subsection{Preparation of $\alpha$-La-Lys nanostructures}

Stock solutions of $\alpha$-La and Lys were prepared as described above. Then, $\alpha$-La-Lys supramolecular structures were formed by mixing quantities of Lys and $\alpha$-La stock solutions to reach the molar stoichiometric determined by ITC analysis. The resulting solution

Table 1

Independent variables and levels in the Box-Behnken experimental design.

\begin{tabular}{llll}
\hline Independent variables & \multicolumn{2}{l}{ Levels } & \\
\cline { 2 - 4 } & Low & Medium & High \\
\hline$X_{1}(\mathrm{pH})$ & $-1(3)$ & $0(7)$ & $1(11)$ \\
$X_{2}$ (Heating temperature) & $-1(25)$ & $0(50)$ & $1(75)$ \\
$X_{3}$ (Heating time) & $-1(15)$ & $0(25)$ & $1(35)$ \\
\hline
\end{tabular}

was then stirred continuously (300 rpm) overnight, to ensure full protein rehydration, at refrigeration temperature $\left(4{ }^{\circ} \mathrm{C}\right)$ in a controlled temperature storage room. To study the effects of $\mathrm{pH}$, temperature and time of heating upon the protein assembly, and therefore in formation of supramolecular structures, the $\mathrm{pH}$ of solution was adjusted to 3, 7 and 11 with $1 \mathrm{~mol} \mathrm{~L}^{-1}$ of $\mathrm{HCl}$ or $\mathrm{NaOH}$, as appropriate, and different temperatures (i.e. 25,50 and $75^{\circ} \mathrm{C}$ ) and times (i.e. 15, 25 and $35 \mathrm{~min}$ ) of heating were applied. After the heat treatment, the solutions were placed in an ice bath for $30 \mathrm{~min}$, and then stored in refrigerated conditions, at $4{ }^{\circ} \mathrm{C}$, until testing. These conditions were chosen based in previous studies carried out by Monteiro (2014).

\subsection{Particle size, polydispersity index and $\zeta$-potential analyses}

Protein supramolecular structures were characterized in terms of size, polydispersity index (PDI) and $\zeta$-potential. The particle size was determined by the method of cumulants fit and translated into average particle diameters (Z-value) using Stokes-Einstein relationship (Anema \& Li, 2003). PDI describes the width or the relative variance of the particle size distribution and is derived from cumulants analysis of the measurements. The $\zeta$-potential measures the electrostatic/charge at the surface of the structure. For this characterization, a dynamic light scattering (DLS) apparatus (Zetasizer Nano ZS, Malvern Instruments, UK) equipped with a $\mathrm{He}-\mathrm{Ne}$ laser at a wavelength of $633 \mathrm{~nm}$ was used. Samples of $1 \mathrm{~mL}$ of $\alpha$-La-Lys solutions were poured into disposable sizing cuvettes with a path length of $12 \mathrm{~mm}$ for size and PDI determination and into a folded capillary cell for $\zeta$-potential analyses. All measurements were carried out at $25 \pm 0.5{ }^{\circ} \mathrm{C}$. Measurements of size and PDI were performed in collected applying backscatter detection NIBS (Non-Invasive Back-Scatter) at $173^{\circ}$, so as to reduces multiple scattering and allowing measurements of higher concentrations. $\zeta$ potential was performed with an angle of $17^{\circ}$, with values calculated by Smoluchowski's model. The results are given as the average \pm standard deviation of nine measurements.

\subsection{Circular dichroism}

The secondary structure of native $\alpha$-La and Lys protein and $\alpha$ La-Lys supramolecular structures were assessed by circular dichroism (CD). CD spectra were obtained with a J-810 spectropolarimeter (Jasco Corporation, Japan) equipped with a temperature controller Peltier PFD 425S (Jasco Corporation, Japan) coupled to a thermostatic bath AWC 100 (Julabo, Germany). The spectra were collected at $25^{\circ} \mathrm{C}$, under constant nitrogen flush, using a quartz cuvette of $10 \mathrm{~mm}$ path length (Hellma Analytics, Germany), from 200 to $260 \mathrm{~nm}$ wavelength range with a data pitch of $0.2 \mathrm{~nm}$ and accumulation of 3 scans. The response time, scan rate and bandwidth were $1 \mathrm{~s}, 200 \mathrm{~nm} \mathrm{~min}{ }^{-1}$, and $1 \mathrm{~nm}$, respectively. These parameters were used based in the procedure adopted by Diniz et al. (2014) and optimized by Monteiro (2014). CD spectra were baseline-corrected by subtracting blank spectra of the corresponding solutions, at the same concentration but without heat treatment and $\mathrm{pH}$ adjustment. At least, ten replicates of each sample were carried out.

\subsection{Fluorescence measurements}

In order to assess conformational changes of $\alpha$-La-Lys supramolecular structures, analysis were performed on a K2 spectrofluorometer (ISS, USA). Measurements were carried out using a quartz cuvette of $10 \mathrm{~mm}$ path length (Hellma Analytics, Germany) at a temperature of $25^{\circ} \mathrm{C}$ maintained by a circulating water bath 9001 (PolyScience, USA). Fluorescence spectra were performed 
with a scanning speed of $240 \mathrm{~nm} \mathrm{~min}{ }^{-1}$ and recorded in the wavelength range of $290-450 \mathrm{~nm}$ upon excitation wavelength at $290 \mathrm{~nm}$, in order to take advantage of tryptophan residues (Lakowicz, 2006). The excitation slit width was set to $5 \mathrm{~nm}$. Spectra were baseline-corrected by subtracting blank spectra, of the corresponding solutions at the same concentration but without heat treatment and $\mathrm{pH}$ adjustment. At least ten replicates of each sample were produced.

\subsection{Optical microscopy}

The morphology of $\alpha$-La-Lys supramolecular structures at $\mathrm{pH}$, obtained for different temperatures (i.e. 25,50 and $75^{\circ} \mathrm{C}$ ) and times (i.e. 15, 25 and $35 \mathrm{~min}$ ) of heating were observed using a phase contrast optical microscope (Olympus BX51TF, Japan) equipped with an Olympus DP72 camera (Olympus, Japan). Samples were put between glass slides, and the structures were immediately observed at a magnification of $100 \times$ at room temperature. At least 3 replicates were performed.

\subsection{Transmission electron microscopy}

Transmission electron microscopy (TEM) imaging of $\alpha$-La-Lys supramolecular structures was conducted on a Zeiss EM 902A (Thornwood, N.Y., USA) microscope at an accelerating voltage of 50 and $80 \mathrm{kV}$. A drop of sample dispersion was deposited onto a carbon support film mounted on a TEM copper grid (Quantifoil, Germany). The excess of solution was removed after 2 min using a filter paper and the grid let for air-drying. The samples were then negatively stained with uranyl acetate ( $2 \% \mathrm{w} / \mathrm{w}$ ) (Merck, Germany) for $15 \mathrm{~s}$. The grid was finally air dried at room temperature before introducing it in the electron microscope. These conditions were used based in procedures usually adopted by our research group (Bourbon et al., 2015; Pinheiro et al., 2015) and optimized by Monteiro (2014) to this sample.

\subsection{Stability}

The stability of $\alpha$-La-Lys supramolecular structures was accessed for the condition showing the most promising results using the analysis performed above, at two different temperatures, $25{ }^{\circ} \mathrm{C}$ (to simulate room conditions) and $4{ }^{\circ} \mathrm{C}$ (to simulate refrigeration) for 150 days of storage period. These conditions were chosen as the standard parameters usually employed to evaluate the stability of nanostructures on food matrices upon storage, as reported by Bourbon et al. (2015). Microorganism growth was prevented by previous adding $0.02 \%$ of $\mathrm{NaN}_{3}$ (used as preservative) into the solutions containing $\alpha$-La-Lys supramolecular structures, following the procedure adopted elsewhere (Pereda, Ponce, Marcovich, Ruseckaite, \& Martucci, 2011; Ramos, Pereira, et al., 2012b). The stability was evaluated in terms of particle size, PDI and $\zeta$-potential by DLS, following the procedure described before. At least 3 replicates were done.

\subsection{Statistical analysis}

The response surfaces remaining statistical analyses were carried out using a statistical package software version 10.0.228.8 (StatSoft Inc.). Such analyses of the data were carried out using Tukey mean comparison test, with the significance level set at $p<0.05$.

\section{Results and discussion}

\subsection{Calorimetric profile}

The protein dispersions of $\alpha$-La and Lys were assessed in terms of their thermal behavior (transition temperatures). DSC measurements revealed the characteristic melting behavior (i.e. melting temperature and enthalpy) of $\alpha$-La and Lys dispersions. The corresponding thermal profile of $\alpha$-La and Lys proteins (in native state), obtained for the temperature range $20-100^{\circ} \mathrm{C}$, is presented in Fig. 1. Two well-defined endothermic peaks were obtained for both proteins. The thermogram with an endothermic peak obtained at $62.7 \pm 0.0{ }^{\circ} \mathrm{C}$, with a transition enthalpy $(\Delta \mathrm{H})$ of $4.62 \pm 0.25 \times 10^{4} \mathrm{cal} \mathrm{mol}^{-1}$ corresponds to the denaturation of $\alpha$-La, showing similar results to those reported elsewhere: i.e. $62.7^{\circ} \mathrm{C}$ with $\Delta \mathrm{H}$ of $4.62 \pm 0.24 \times 10^{4} \mathrm{cal} \mathrm{mol}^{-1}$ (Diniz et al., 2014), $63.8^{\circ} \mathrm{C}$ with $\Delta H$ of $4.19 \pm 0.32 \times 10^{4} \mathrm{cal} \mathrm{mol}^{-1}$ (Ramos, Pereira, et al., 2012b) and $63.9{ }^{\circ} \mathrm{C}$ with $\Delta \mathrm{H}$ of $6.84 \pm 1.2 \times 10^{4} \mathrm{cal} \mathrm{mol}^{-1}$ (McGuffey, Epting, Kelly, \& Foegeding, 2005). On the other hand, the thermogram with an endothermic peak obtained at $77.0 \pm 0.0^{\circ} \mathrm{C}$, with $\Delta \mathrm{H}$ of $1.23 \pm 0.028 \times 10^{5} \mathrm{cal} \mathrm{mol}^{-1}$ is attributed to denaturation of Lys, which is similar to that reported by elsewhere, i.e. $74.6{ }^{\circ} \mathrm{C}$ with $\Delta \mathrm{H}$ of $1.02 \pm 0.03 \times 10^{5} \mathrm{cal} \mathrm{mol}^{-1}$ (Blumlein \& McManus, 2013) and $76.2{ }^{\circ} \mathrm{C}$ with $\Delta \mathrm{H}$ of $1.30 \pm 0.08 \times 10^{5} \mathrm{cal} \mathrm{mol}^{-1}$ (Shih \& Kirsch, 1995). These transitions are obtained for similar $\mathrm{pH}$ conditions and are believed to occur because of disruption of forces stabilizing native protein structures (e.g. hydrophobic and electrostatic interactions, as van der Waals and hydrogen bonds) and hydration of the exposed residues (Gill et al., 2010). Although $\alpha$-La and Lys are two related proteins, having a similar amino acid sequences (ca. 40\%) and a threedimensional structure, including four disulfide bonds (Nigen et al., 2007), Lys (in its native form) showed to be more stable than $\alpha$-La once the endothermic peak was displayed at higher temperatures and with greater $\Delta \mathrm{H}$ values - thus implying that higher energy was needed to disrupt interactions during denaturation. This observation is in agreement with that obtained elsewhere (Nigen et al., 2007).

The small changes verified for both proteins when compared with the data reported elsewhere may be derived from the different experimental conditions used such as protein source and ionic strength (Diniz et al., 2014).

The temperature of $75^{\circ} \mathrm{C}$ was used as the maximum working temperature based on the thermal behavior obtained for the $\alpha$-La and Lys protein dispersions in native state (i.e. $\mathrm{pH}$ of 7.3 and 4.3 for $\alpha$-La and Lys, respectively). The working temperatures were also set

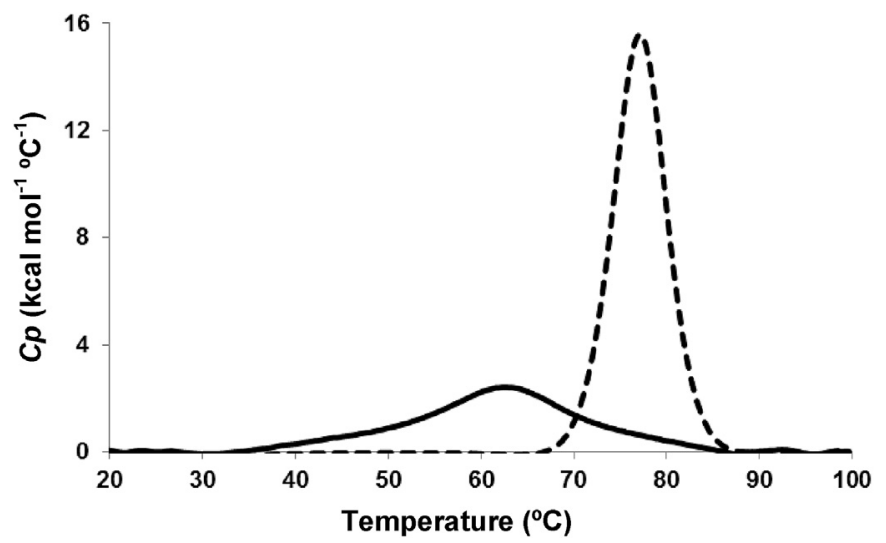

Fig. 1. DSC thermogram showing heat capacity (Cp) versus temperature for $\alpha$-La(-) and Lys (- ) protein solutions at $2 \mathrm{mg} \mathrm{mL}^{-1}$. 
at $25^{\circ} \mathrm{C}$ (used to simulate the room temperature) and $50{ }^{\circ} \mathrm{C}$ (used as average of the first two temperatures, following the proposed BoxBehnken experimental design) - with the goal of evaluating formation of supramolecular structures at lower denaturation temperatures.

\subsection{Isothermal titration calorimetry}

The effect of associating $\alpha$-La with Lys was assessed by ITC. The heat flow versus time profile resulting from the titration of Lys with $\alpha$-La at $25{ }^{\circ} \mathrm{C}$ is shown in Fig. 2 (top panels). The area under each peak represented the heat exchange within the system after each injection. The results showed that the injection profile of Lys in the sample cell containing $\alpha$-La was exothermic and decreased regularly to become endothermic and constant after the 10th injection (corresponding to $\alpha$-La/Lys molar ratio of 0.546 ). The endothermic signal after ten injections was attributed to the dilution signal of Lys in the sample cell, as assessed by comparison with a reference experiment. A similar behavior was reported elsewhere (Nigen et al., 2007), which exhibited an exothermic and endothermic contribution in the first 13 injections that become endothermic after the 14th injection for ITC of apo $\alpha$-La with Lys at same temperature (i.e. $25^{\circ} \mathrm{C}$ ).

The values of $\Delta H^{\circ}$ representing the enthalpy energy absorbed or released when $\alpha$-La interacts with Lys, shown in Fig. 2 (bottom panels), are obtained by integration of the isotherm peaks and

Time (min)

$-100102030405060708090100110120130140$

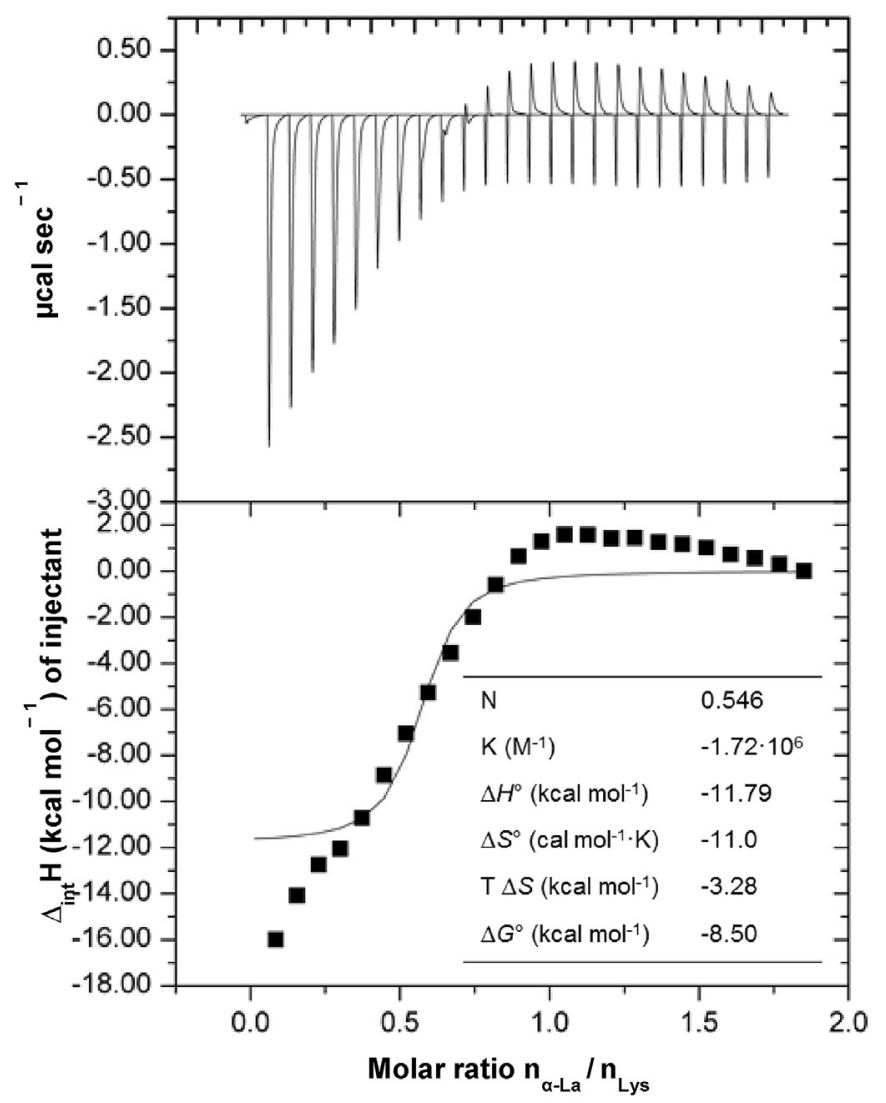

Fig. 2. ITC $\alpha$-La and Lys protein solutions at $25^{\circ} \mathrm{C}$. Top panels represent the raw heat signal for the titration of Lys $\left(2 \mathrm{mg} \mathrm{mL}^{-1}\right)$ with successive increments of $\alpha$-La concentration. Bottom panels represent the area under each peak integrated and plotted against the Lys/ $\alpha$-La molar ratio. subtraction of the heats of Lys dilution into the standard solution. The magnitude of $\Delta H^{\circ}$ reflects the contributions of four main processes: (i) association/dissociation of ions with charged groups on the proteins $\left(\Delta_{\text {int }} H_{i}\right)$, giving rise to an exothermic process; (ii) association of $\alpha$-La with Lys $\left(\Delta_{\text {int }} H_{\alpha \text {-La-Lys }}\right)$, referring to the interaction occurring between $\alpha$-La and Lys; (iii) changes in the solvation of the proteins $\left(\Delta_{\text {int }} H_{\text {sol }}\right)$, resulting in a endothermic process since it requires the interactions of $\mathrm{H}_{2} \mathrm{O}$-Lys, Lys-ion, ion- $\alpha$-La, and $\mathrm{H}_{2} \mathrm{O}-\alpha$-La; and (iv) rearrangement of the protein molecular structure $\left(\Delta_{\text {int }} H\right.$ conf.rear.), giving rise to an endothermic process as the intramolecular interactions are broken. These four main processes can be related with each other using the following equation:

$\Delta H^{\circ}=\Delta_{\text {int }} H_{i}+\Delta_{\text {int }} H_{\alpha-\text {-La-Lys }}+\Delta_{\text {int }} H_{\text {sol }}+\Delta_{\text {int }} H_{\text {conf.rear }}$

values of $\Delta_{\text {int }} H$ are initially exothermic and become increasingly more negative due to the contributions of endothermic processes according with Eq. (1): $\Delta_{\text {int }} H_{\text {sol }}$ and $\Delta_{\text {int }} H_{\text {conf.rear }}$ In addition to the cleavage of the interactions in the process $\Delta_{\text {int }} H_{\text {sol }}$, the protein-water and protein-ion interactions may be also broken. These interactions are quite intense, as they are characterized by hydrogen bonds and electrostatic attractions, respectively. Furthermore, in the interaction between proteins $\alpha$-La-Lys, the proteins change their conformation exposing the hydrophilic groups that became free to interact, as can be observed in the fluorimetry results (presented below). Increasing the $\alpha$-La-Lys molar ratio increases the contribution of the endothermic processes until achieving similar values of the enthalpy of exothermic processes; this can be experimentally seen by the change in enthalpy that becomes approximately zero (as shown in Fig. 2).

In the course of the titration, the heat released decreased ca. $12 \mathrm{kcal} \mathrm{mol}^{-1}$ for molar ratios ranging from ca. 0.30 to 0.80 of $\alpha$-La injected. Afterwards, the Lys molecules become saturated with $\alpha$-La (for a molar ratio between 0.8 and 1) and attained a plateau for a molar ratio higher than 1.0. This result was similar to that obtained by (Nigen et al., 2007), which reached the saturation of apo $\alpha$-La with Lys at a molar ratio of ca. 1 for ITC carried out at the same temperature.

The curve of heat integration according to the molar ratio between the reactants was adjusted and the thermodynamic interaction parameters mentioned above $\left(N, K, \Delta H^{\circ}, \Delta G^{\circ}\right.$ and $\left.\Delta S^{\circ}\right)$ were determined, using the MicroCal VP-DSC software, and presented in Fig. 2.

The stoichiometric coefficient $(N)$ obtained was 0.546 , thus the $\alpha$-La-Lys supramolecular structures were produced by mixing dispersions of $2 \mathrm{mg} \mathrm{mL}^{-1}$ of $\alpha$-La and Lys proteins in a molar ratio of 0.546:1 ( $\alpha$-La:Lys). Under these conditions, the $\alpha$-La and Lys have a strong exothermic interaction $\left(\Delta H^{\circ}\right.$ of $\left.-1.179 \times 10^{4} \mathrm{cal} \mathrm{mol}^{-1}\right)$. Moreover, as the entropy obtained is lower than zero $\left(\Delta S^{\circ}\right.$ of $-11.00 \mathrm{cal} \mathrm{mol}^{-1} \mathrm{~K}^{-1}$ ) indicates that conformational change between the proteins molecules may be occurring and thus interactions among $\alpha$-La and Lys proteins, being the process enthalpically driven (Diniz et al., 2014).

\subsection{Electrostatic properties}

The association between $\alpha$-La and Lys depends on the balance between attractive and repulsive forces and therefore it is highly dependent on environmental conditions such as pH (Nigen, Le Tilly, et al., 2009b). In order to evaluate the $\mathrm{pH}$ conditions that promote the development of electrostatic interactions between $\alpha$-La and Lys, $\zeta$-potential values of individual solutions of $\alpha$-La and Lys and of the product of $\zeta$-potential values from both protein solutions were determined, at several $\mathrm{pH}$ values, ranging from 3 to 11, as shown in Fig. 3a. 

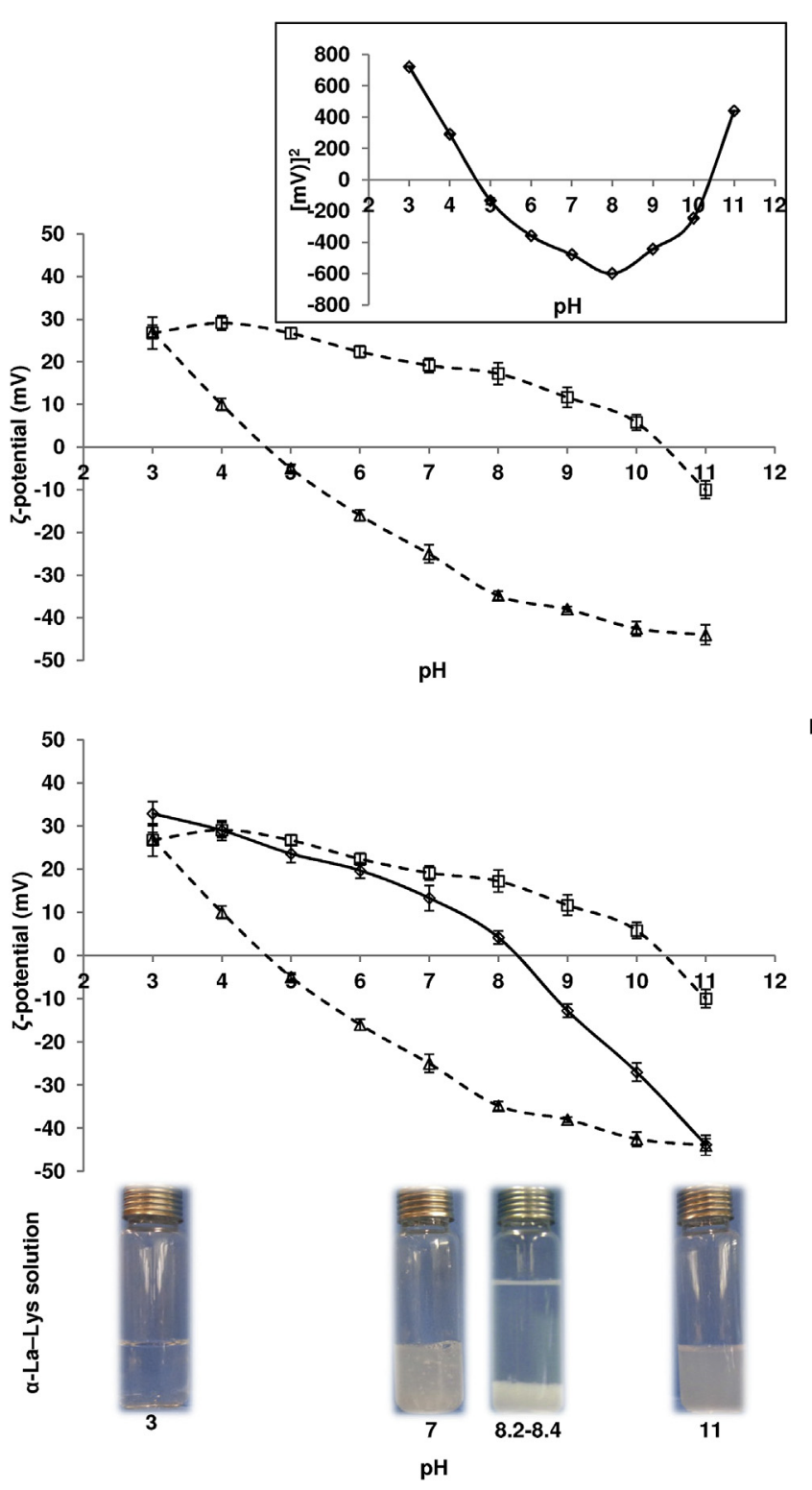

Fig. 3. Electrostatic properties i.e. $\zeta$-potential) of a) individual $\alpha$-La ( $\bigcirc)$ and Lys ( $\square$ ) solutions as a function of $\mathrm{pH}$ (inset figure shows the product of these $\zeta$-potentials, in a $\alpha$-La:Lys molar ratio of $0.546: 1$, from $\mathrm{pH} 3$ to 11 ); and b) $\alpha$-La-Lys solution $(\diamond)$, (prepared at $2 \mathrm{mg} \mathrm{mL}^{-1}$ in a $\alpha$-La:Lys molar ratio of $0.546: 1$ ) as function of $\mathrm{pH}$ (curves of individual $\alpha$-La $(O)$ and Lys $(\square)$ protein solutions are shown for comparative purposes). Each data point is the average and the error bars show the standard deviation. Images show the aspect of $\alpha$-La-Lys solution as result of these $\zeta$-potentials for $\mathrm{pH} 3,7$, $8.2-8.4$ and 11 .

$\alpha$-La solution changed its charge from positive $\zeta$-potential $(27.0 \pm 1.6 \mathrm{mV})$ at $\mathrm{pH} 3$ to negative $(-44.0 \pm 2.3 \mathrm{mV})$ at $\mathrm{pH} 11$, and attained its zero charge (i.e. $\zeta$-potential $=0 \mathrm{mV}$ ) at ca. $\mathrm{pH} 4.8$, as reported in previous publications (He et al., 2013; Ramos et al., 2014; Sgarbieri, 2005b). At this point (known as the pI) the net charge of $\alpha$-La protein approaches zero, so electrostatic repulsions weaken and molecules of $\alpha$-La (particularly those in the denatured state) likely aggregates. For Lys, the $\zeta$-potential changed from $26.8 \pm 3.8$ to $-10.0 \pm 2.1 \mathrm{mV}$ for $\mathrm{pH}$ from 3 to 11 , respectively. The $\mathrm{pI}$ was observed at ca. $\mathrm{pH} 10.6$, which is in agreement with other reported studies (He et al., 2013; Luding, Shaochuan, Junxian, \& Kejian, 2011). The product of $\zeta$-potentials reached a minimum at ca. $\mathrm{pH} 8$, suggesting that the strongest electrostatic attraction between these proteins should occur at this $\mathrm{pH}$ value (Bourbon et al., 2015).

On the other hand, $\alpha$-La-Lys solution varied its charge from positive $\zeta$-potential $(+32.9 \pm 2.8 \mathrm{mV})$ at $\mathrm{pH} 3$ to negative $(-43.8 \pm 1.4 \mathrm{mV})$ at $\mathrm{pH} 11$, exhibiting a zero charge at $\mathrm{pH}$ between 8.2 and 8.4. At this point, perceived as the pI of $\alpha$-La-Lys solution, the net charge of the protein system approaches zero, so denatured molecules of both proteins ( $\alpha$-La and Lys) aggregate, resulting in loss of stability of the protein system and therefore leading to phase separation (Ramos et al., 2014) - as can be seen in Fig. 3b (picture insertion at $\mathrm{pH}$ ranging from 8.2 to 8.4 ). At $\mathrm{pH} 7$, the $\zeta$-potential value was of $+13.3 \mathrm{mV}$, which is close to the $\mathrm{pI}$ of $\alpha$-La-Lys solution, meaning that the electrostatic attraction between both proteins is dominant, which results in the formation of a highly turbid solution (opaque) with the presence of visible insoluble precipitates (see Fig. 3b, picture insertion at $\mathrm{pH}$ of 7). The $\alpha$-La-Lys solution at $\mathrm{pH} 3$ and 11 may have a good colloidal stability once it has been reported that structures presenting $\zeta$-potential values higher than $+30 \mathrm{mV}$ or lower than $-30 \mathrm{mV}$, are generally regarded as stable because of the strong repulsion forces that prevent the occurrence of aggregation among protein molecules (Liu et al., 2012). Moreover the $\zeta_{-}$ potential values reached a minimum at $\mathrm{pH} 11$, indicating that the strongest electrostatic repulsion between these two proteins should happen near this $\mathrm{pH}$ value ( $\alpha$-La-Lys system more stable), whereas the strongest electrostatic attraction should occur at $\mathrm{pH}$ near the pI of $\alpha$-La-Lys system, when net charge approaches zero.

\subsection{Particle size and polydispersity index analyses}

Although many proteins are able to self-assemble into welldefined structures, the propensity to do so under given circumstances and the properties of final structures can vary markedly from a protein to another, with strong dependence on the physicochemical conditions of the medium i.e. $\mathrm{pH}$, temperature and time of heating, ionic strength, among others (Nigen, Le Tilly, et al., 2009b). Therefore, the influence of several $\mathrm{pH}$ values and thermal treatments (i.e. different temperatures and times of heating) on supramolecular structures formation were evaluated by DLS following the experiment design of Box-Behnken.

Table 2 shows the coefficients and $p$-values of a response surface regression analysis calculated for particle size $\left(Y_{1}\right)$ and PDI $\left(Y_{2}\right)$ using a 2-way interaction (linear and quadratic) model. Here a confidence level of $95 \%$ was used, thus a factor is considered to affect the response if the coefficients differ from zero significantly

Table 2

Regression coefficients and associated probability values (p-value) for responses of particle size $\left(\mathrm{Y}_{1}\right)$ and polydispersity index $\left(\mathrm{Y}_{2}\right)$.

\begin{tabular}{|c|c|c|c|c|}
\hline \multirow[t]{2}{*}{ Term } & \multicolumn{2}{|l|}{$Y_{1}$} & \multicolumn{2}{|l|}{$Y_{2}$} \\
\hline & Coefficient & $p$-value & Coefficient & $p$-value \\
\hline Constant & 3204.24 & $<0.001$ & 0.445833 & $<0.001$ \\
\hline$X_{1}(\mathrm{~L})$ & -90.18 & 0.52000 & -0.097500 & 0.006272 \\
\hline$X_{1}(\mathrm{Q})$ & 3448.94 & 0.00056 & 0.077708 & 0.004824 \\
\hline$X_{2}(\mathrm{~L})$ & -1982.67 & 0.00344 & -0.020833 & 0.115194 \\
\hline$X_{2}(\mathrm{Q})$ & -1006.31 & 0.00648 & -0.062292 & 0.007477 \\
\hline$X_{3}(\mathrm{~L})$ & -217.58 & 0.20289 & 0.009167 & 0.358830 \\
\hline$X_{3}(\mathrm{Q})$ & -960.82 & 0.00710 & -0.024792 & 0.044570 \\
\hline$X_{1}(\mathrm{~L}) * X_{2}(\mathrm{~L})$ & -81.82 & 0.65298 & -0.047500 & 0.044812 \\
\hline$X_{1}(\mathrm{~L})^{*} X_{2}(\mathrm{Q})$ & -12.91 & 0.91770 & -0.060000 & 0.014715 \\
\hline$X_{1}(\mathrm{Q}) * X_{2}(\mathrm{Q})$ & -2889.81 & 0.00146 & 0.055000 & 0.017439 \\
\hline$X_{1}(\mathrm{~L})^{*} X_{3}(\mathrm{~L})$ & 68.50 & 0.70411 & -0.047500 & 0.044812 \\
\hline$X_{1}(\mathrm{Q}) * X_{3}(\mathrm{~L})$ & -286.25 & 0.12240 & 0.107500 & 0.004655 \\
\hline$X_{2}(\mathrm{~L})^{*} X_{3}(\mathrm{~L})$ & 850.75 & 0.03216 & 0.037500 & 0.069143 \\
\hline$R^{2}$ & 0.9995 & & 0.9981 & \\
\hline
\end{tabular}

Note: Statistically significant $(p$-value $<0.05) ; X_{1}: \mathrm{pH} ; X_{2}$ : temperature of heating; $X_{3}$ : time of heating; L: linear; Q: Quadratic; $R^{2}$ : coefficient of determination. 
and the $p$-value is less than $0.05(p<0.05)$. Therefore, the regression models of $Y_{1}$ and $Y_{2}$ were simplified by including only statistically significant coefficients shown in Table 2. The positive sign of a coefficient represents that the response increases with the factor (i.e. increasing $\mathrm{pH}$, temperature or time lead to progressively large particle sizes or higher PDI values); while a negative sign means that the response and factors have inverse relation (i.e. increasing $\mathrm{pH}$, temperature or time will decrease particle sizes or PDI values).

The data presented in Table 2 reveals that the adjusted model to the Box-Behnken design was adequate and a good representation of the effect of such factors upon supramolecular structure formation was attained, with coefficient of determination $\left(R^{2}\right)$ values for particle size and PDI of 0.9995 and 0.9981 , respectively, indicating a good fit between predicted values and the experimental data points.

According to the fitted model (see Table 2), the quadratic terms of all independent variables tested (i.e. $\mathrm{pH}$, temperature and time of heating) exhibited statistical significance $(p<0.05)$ for both dependent variables. On the other hand, only the linear term of heating temperature and $\mathrm{pH}$ has shown statistical significance $(p<0.05)$ for particle size and PDI, respectively. The quadratic interactions between $\mathrm{pH}$ and temperature of heating and the linear interactions between temperature and time of heating for particle size, have reached statistical significance $(p<0.05)$. Regarding PDI, all interactions (i.e. between $\mathrm{pH}$ and temperature, $\mathrm{pH}$ and time or temperature and time) at linear and quadratic terms, have showed statistical significance $(p<0.05)$. It is thus clear that changes in the above factors significantly affect the particle size and PDI of $\alpha$ La-Lys resulting supramolecular structures.

By analyzing the surface plots (Figs. 4 and 5) the critical conditions for the formation of $\alpha$-La-Lys supramolecular structures can be assessed.

Fig. 4 a shows the effect of different temperatures of heating (i.e. from 25 to $75^{\circ} \mathrm{C}$ ) and $\mathrm{pH}$ values (i.e. from 3 to 11 ) in size of $\alpha$-La-Lys supramolecular structures resulting from self-assembly of $\alpha$-La and Lys. It is possible to observe the formation of $\alpha$-La-Lys supramolecular structures with significantly higher $(p<0.05)$ sizes at $\mathrm{pH} 7$, in the microscale, ranging from ca. 2.5 to values higher than $10 \mu \mathrm{m}$ (beyond the size limit that could be analyzed by DLS) depending on the temperature employed (Fig. 4a).

Therefore, the formation of such structures at $\mathrm{pH} 7$, as well as the size values was confirmed by optical microscopy (results not shown). From microscopy analysis, it was possible to observe the formation of aggregates with irregular shape estimated to range from 2 to $20 \mu \mathrm{m}$ according with the heat treatment (i.e. temperature and time employed). These microscopy results confirm the size range obtained by DLS analysis. According to size values of the aggregates observed by optical microscopy, the structures formed at $\mathrm{pH} 7$ were not further analyzed after this period. The formation of supramolecular structures at the microscale (i.e. $3269 \mathrm{~nm}$ ) resulting from apo $\alpha$-La and Lys prepared at similar molar ratio (i.e. $\alpha$-La:Lys; 0.5:1) and $\mathrm{pH}$ (i.e. 7.5) conditions has also been reported, possibly (Nigen et al., 2007). The size values at microscale obtained at pH 7 (or at pH 7.5 in the case of the work reported by Nigen et al. 2007), may be due to the fact that this $\mathrm{pH}$ is relatively close to the $\mathrm{pI}$ of $\alpha$-La-Lys mixture (i.e. between 8.2 and 8.4); at these conditions the net charge of the protein approaches zero, so electrostatic repulsions weaken and proteins likely aggregate (Ramos, Pereira, et al., 2012b). This phenomenon was experimentally determined by $\zeta$-potential measurements as showed above in Fig. 3.

Moreover, it is shown that at low (i.e. 3) and high (i.e. 11) pH values the protein supramolecular structures presented an average size closer or within the nanoscale range (i.e. lower than $406 \mathrm{~nm}$ ) (Fig. 4a) These variations along pH (from 3 to 11) confirm the quadratic interactions obtained between $\mathrm{pH}$ and temperature - as shown in Table 2 . The size values were significantly lower $(p<0.05)$ when the structures were formed at a temperature of $75^{\circ} \mathrm{C}$, ranging from ca. $61.5 \pm 2.3$ to $154.5 \pm 3.3 \mathrm{~nm}$ for $\mathrm{pH} 11$ and from ca. $215 \pm 23.5$ to $406 \pm 40.1 \mathrm{~nm}$ for $\mathrm{pH} 3$ (Fig. 4a). These variations among each $\mathrm{pH}$ value may be influenced by the heating time used, as can be inferred by the statistically significant effect $(p<0.05)$ (quadratic interaction) of time $\left(X_{3}\right)$ upon particle size - see Table 2.

Fig. $4 \mathrm{~b}$ shows the effect of different temperatures (i.e. from 25 to $75^{\circ} \mathrm{C}$ ) and times (from 15 to $35 \mathrm{~min}$ ) of heating in size of $\alpha$-La-Lys supramolecular structures. It is possible to see a significant decrease $(p<0.05)$ in size of $\alpha$-La-Lys supramolecular structures with the progressive increase of temperature of heating (from 25 to $75^{\circ} \mathrm{C}$ ) (Fig. 4b). The same conclusion can be obtained from the negative sign of both coefficients (i.e. linear and quadratic, -1982.67 and -1006.31 , respectively), of heating temperature $\left(X_{2}\right)$ for particle size - thus meaning that the response (particle sizes) is inversely proportional to the factor (heating temperature). This observation could be explained by the presence of some protein aggregates in solution at $25{ }^{\circ} \mathrm{C}$ that were progressively solubilized with the temperature increase. This finding is in agreement with several authors that reported that "soluble aggregates" may be formed prior to the development of gels under conditions that are below the critical protein concentration or heating temperatures/times that cause gelation (McSwiney, Singh, \& Campanella, 1994; Ryan, Zhong, \& Foegeding, 2013). Moreover it is possible to observe a significant increase $(p<0.05)$ in size of $\alpha$ La-Lys supramolecular structures with the increase of time of heating (from 15 to $35 \mathrm{~min}$ ) for temperatures higher than $50{ }^{\circ} \mathrm{C}$ (Fig. 4b). This result can be due to structural changes that may happen in the $\alpha$-La protein of supramolecular system for temperatures higher than $50{ }^{\circ} \mathrm{C}$ (as indicated by the thermal transition recorded by DSC, for native $\alpha$-La at this temperature - Fig. 1). This effect can be also inferred from the positive sign of the coefficient obtained for the linear relation between temperature and time of heating (i.e. 850.75) for particle size, thus suggesting that particle sizes varies proportionally to temperature and time of heating see Table 2. On the other hand, the progressive increase $(p<0.05)$ in size obtained for $\alpha$-La-Lys supramolecular structures during the heating time (Fig. 4b) may be due to a continuous crosslinking process between the protein molecules that occurs with a prolonged thermal treatment, during the formation of supramolecular structures. According to several authors (Nicolai \& Durand, 2013; Ramos et al., 2014; Ryan et al., 2013) such continuous building process occurring during heating time leads to a progressively larger embranchment of protein molecules which increases the size of the ramified protein chains, thus increasing the overall size of the supramolecular structures, while decreasing their homogeneity and solubility.

Regarding PDI, the results showed that values were the lowest $(p<0.05)$ for supramolecular structures at $\mathrm{pH} 11$, ranging from $0.14 \pm 0.03$ to $0.45 \pm 0.21$, depending on the temperature and time of heating used (Fig. 5a and b, respectively). Moreover, $\alpha$-La-Lys supramolecular structures prepared at $\mathrm{pH} 11$ showed the lowest $(p<0.05)$ PDI values when heated at temperatures higher than $60{ }^{\circ} \mathrm{C}$ (Fig. 5a). For structures formed at $75^{\circ} \mathrm{C}$, under more alkaline conditions (i.e. $\mathrm{pH} 11)$, displayed the lowest $(p<0.05)$ PDI values, suggesting the formation of more monodisperse $\alpha$-La-Lys supramolecular structures than those formed at neutral or acidic conditions.

It is also possible to see a significant decrease $(p<0.05)$ in PDI of $\alpha$-La-Lys supramolecular structures with the progressive increase of temperature of heating (Fig. 5b), which can be confirmed by the negative sign of coefficient (linear and quadratic terms) of heating temperature for PDI, indicating that the response (PDI) is inversely proportional to the factor (heating temperature) - see Table 2 . This 
a)
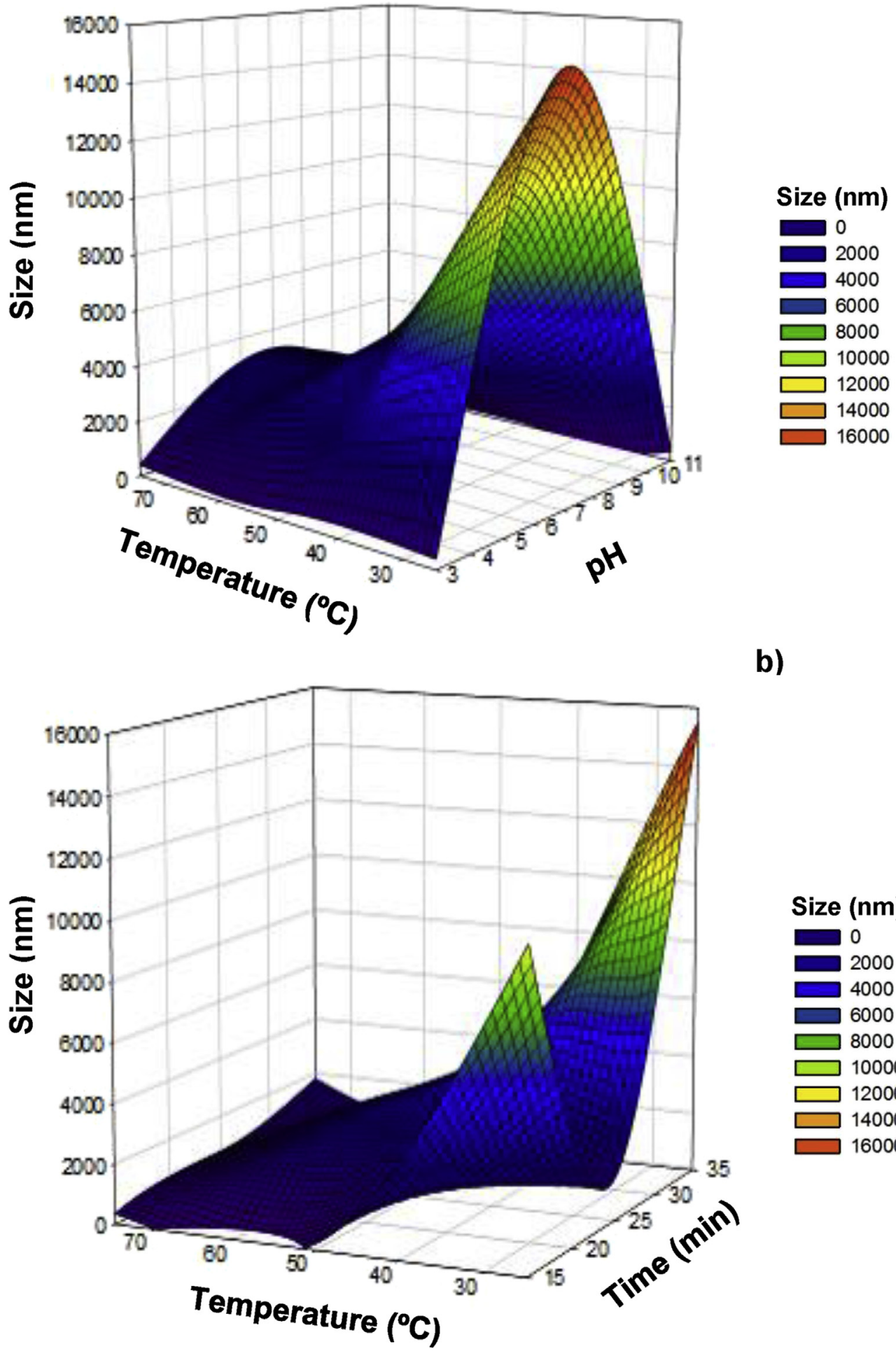

b)

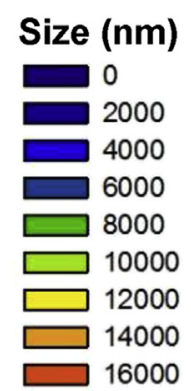

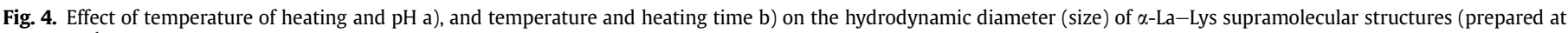
$2 \mathrm{mg} \mathrm{mL}{ }^{-1}$, in a $\alpha$ - La:Lys molar ratio of $0.546: 1$ ).

finding can be related with the significant decrease in size of $\alpha$ La-Lys structures when the heating temperature is increased (as mentioned above). The presence of some protein aggregates in solution at $25^{\circ} \mathrm{C}$ is a result of polydisperse samples, thus leading to higher PDI values. As the temperature increases, the aggregates are progressively solubilized giving rise to more homogenous and monodisperse samples (McSwiney et al., 1994; Ryan et al., 2013). Similar to what happened with size of $\alpha$-La-Lys supramolecular 


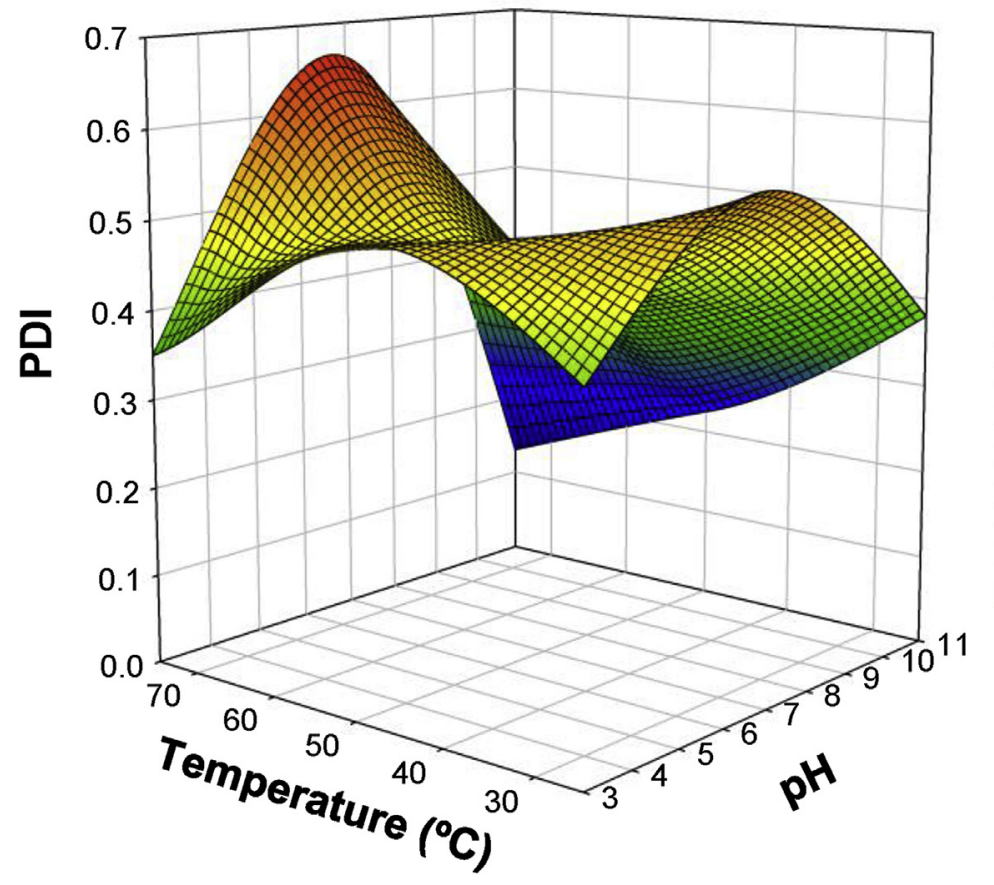

PDI

b)

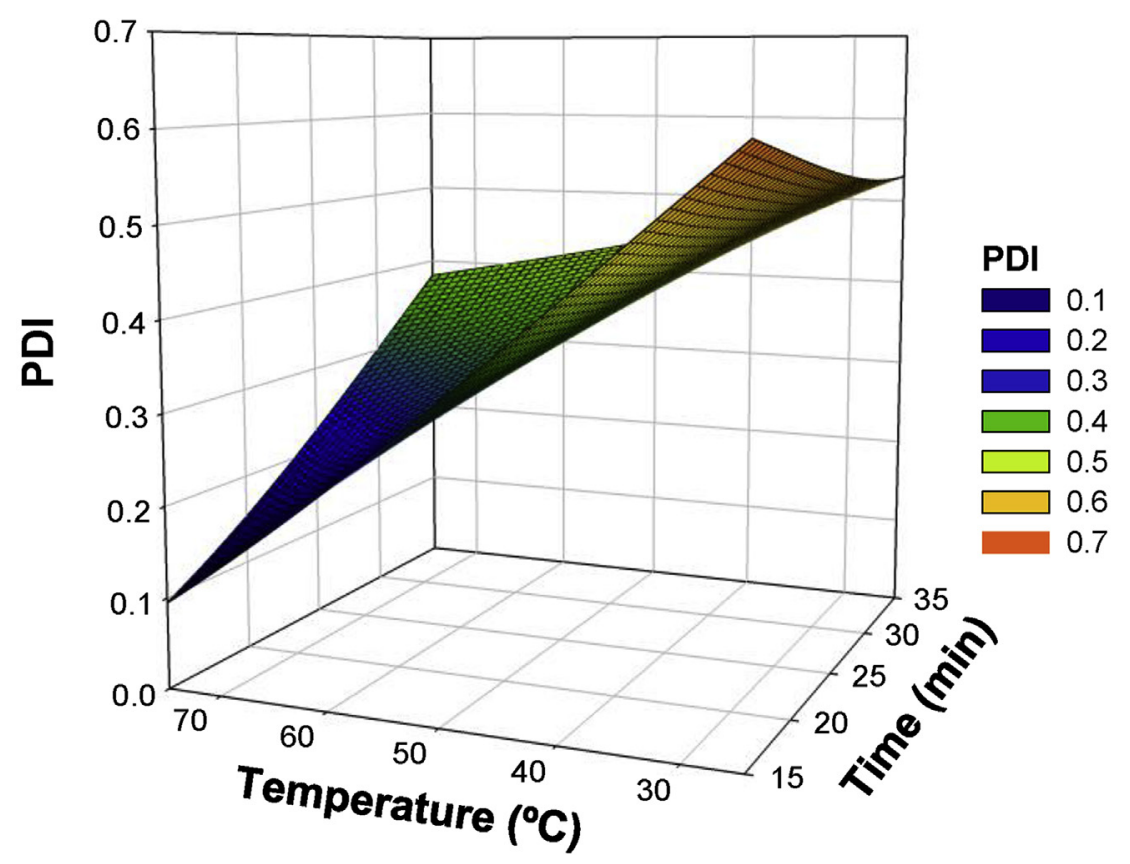

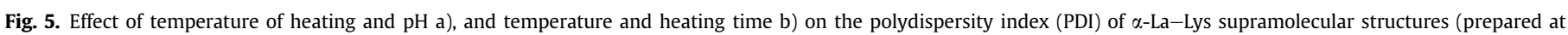
$2 \mathrm{mg} \mathrm{mL}^{-1}$, in a $\alpha$ - La:Lys molar ratio of $0.546: 1$ ).

structures along time of heating, the PDI also significantly increased $(p<0.05)$ - as can be seen in Fig. 5b and from the positive sign (i.e. 0.037500 ) of coefficient between temperature and time of heating for PDI (Table 2). This behavior suggests that longer periods of heating induce a particle size distribution, thus contributing to a more heterogeneous solution, as reported elsewhere (Diniz et al., 2014; Ryan et al., 2013). The increase was more evident for temperatures of heating higher than $50{ }^{\circ} \mathrm{C}$, being the highest increase $(p<0.05)$ obtained at $75{ }^{\circ} \mathrm{C}$ (Fig. 5b). These results showed that the conditions that led to the formation of supramolecular structures with lowest $(p<0.05)$ PDI values were $75^{\circ} \mathrm{C}$ for $15 \mathrm{~min}$, suggesting that this can be the critical heating temperature/time point for their formation (Nicolai \& Durand, 2013; Ramos et al., 2014; Ryan et al., 2013). 


\subsection{Circular dichroism}

The far UV CD spectrum (200-260 nm) conveys information on the secondary structure of proteins, as it measures the absorption of polarized light by peptide bonds of the polypeptide. As a result, the protein secondary structure composed by $\alpha$-helix, $\beta$-sheet, $\beta$ turns and random coil induces the appearance of characteristic bands in specific regions of the $\mathrm{CD}$ spectrum with different shapes, magnitudes and wavelengths. The values recorded at these wavelengths for native $\alpha$-La and Lys proteins were compared to those of $\alpha$-La-Lys supramolecular structures in order to evaluate the changes in the secondary structure that could occur in the protein system, as a function of $\mathrm{pH}$ ( 3 and 11 ), temperature $\left(25\right.$ and $75{ }^{\circ} \mathrm{C}$ ) and time (15 and 35) of heating, as depicted in Fig. 6.

The native spectrum of $\alpha$-La and Lys exhibited a negative peak at $208 \mathrm{~nm}$ (more prominent) and a large band with negative ellipticity intensity at ca. $222 \mathrm{~nm}$ indicating that the secondary structures of those proteins are rich in $\alpha$-helices (Greenfield, 1999; Jindal \& Naeem, 2013); however native $\alpha$-La displayed a peak with higher negative signal intensity than Lys. A similar behavior was found by He et al. (2013) for native $\alpha$-La and Lys prepared at $1.5 \mathrm{mg} \mathrm{mL}^{-1}$, by
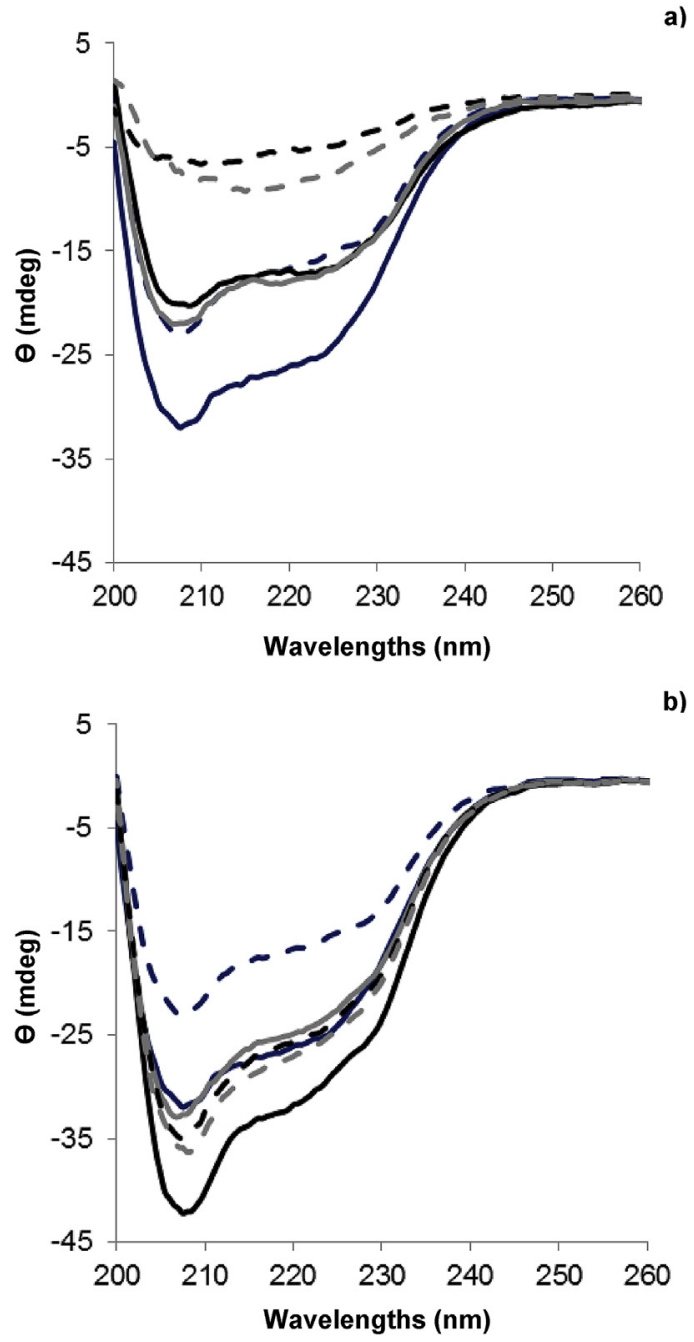

Fig. 6. CD spectra of native $\alpha$-La (-) and Lys (- -) proteins (blue lines), and $\alpha$-La-Lys supramolecular structures (prepared at $2 \mathrm{mg} \mathrm{mL}^{-1}$, in a $\alpha$-La:Lys molar ratio of 0.546:1) obtained at $25^{\circ} \mathrm{C}$ during $15(-)$ and $35(-)$ min and at $75^{\circ} \mathrm{C}$ during $15(--)$ and $35(--)$ min, at (a) pH 11 and (b) $\mathrm{pH} 3$ (For interpretation of the references to color in this figure legend, the reader is referred to the web version of this article).
Diniz et al. (2014) for native $\alpha$-La, prepared at $1.5 \mathrm{mg} \mathrm{mL}^{-1}$ and by Bobály et al. (2014) for native Lys prepared at $2.3 \mathrm{mg} \mathrm{mL}^{-1}$; these authors observed negative peaks at approximately 208 and $222 \mathrm{~nm}$, which are typical of well-defined $\alpha$-helix-rich proteins.

The CD spectra (Fig. 6) were different for $\alpha$-La-Lys supramolecular structures prepared under different conditions (i.e. $\mathrm{pH}$, temperature and time of heating), thus indicating that new regular secondary structures may have formed during protein assembling, dependent on such conditions. This result is in agreement with the CD analysis conducted by Diniz et al. (2014), who observed formation of a new structure ( $\alpha$-lactalbumin-glycomacropeptide) from assembling of $\alpha$-La and GMP, as a function of $\mathrm{pH}$ (i.e. from 3.5 to 6.5), temperature (i.e. from 3.5 to 6.5 ) and time (i.e. from 20 to $40 \mathrm{~min}$ ) of heating.

From Fig. 6 it is possible to conclude that $\alpha$-La-Lys supramolecular structures prepared at both $\mathrm{pH}$ values (i.e. $\mathrm{pH} 3$ and 11), when treated at $25{ }^{\circ} \mathrm{C}$ for 15 and $35 \mathrm{~min}$, maintained the overall characteristics expected for an $\alpha$-helix-rich protein structure (Greenfield, 1999; Jindal \& Naeem, 2013) - Fig. 6a and b. However, at $\mathrm{pH} 11$ the negative peak around $208 \mathrm{~nm}$ displayed a lower negative signal intensity when compared with $\alpha$-La native protein, but similar to the Lys native protein (Fig. 6a). This suggests that structural changes may have occurred in the protein secondary structure of the $\alpha$-La-Lys system (Jindal \& Naeem, 2013), and that they are mainly governed by a higher contribution of Lys in the protein supramolecular structure. At pH 11 - close to the pI of Lys (10.6) - disruption of disulfide bonds responsible for the stabilization of Lys structure may have occurred, thus leading to conformational changes in $\alpha$-La-Lys system (He et al., 2013).

On the other hand, at pH 3 the negative peak around $208 \mathrm{~nm}$ exhibited higher negative signal intensity than those recorded for both spectra of native $\alpha$-La and Lys (Fig. 6b). At this $\mathrm{pH}$, unlike what happened at $\mathrm{pH} 11$, the changes observed in $\alpha$-La-Lys structures (compared with proteins in their native form) are probably attributed to the higher impact of $\alpha$-La in the protein system, as pH 3 is relatively close to its $\mathrm{pI}$ (i.e. 4.8). This finding is consistent with the reported by Diniz et al. (2014) during the assembling of $\alpha$-La and glycomacropeptide at similar $\mathrm{pH}$ conditions (i.e. 3.5). The behavior of $\alpha$-La can be explained by the fact that at low $\mathrm{pH}$, it undergoes a conformational change to the molten globule state, losing its stable tertiary structure, as a result of the alterations occurred in the environment of the tryptophan residues (Ryu, Czarnik-Matusewicz, Dukor, Nafie, \& Jung, 2012).

These observations for Lys and $\alpha$-La are consistent with previous reports (Nicolai \& Durand, 2013; Ramos et al., 2014), which claim that for multiprotein systems, the interactions established among proteins are mainly governed by the protein molecule most affected by environmental conditions (i.e. $\mathrm{pH}$ and ionic strength).

Moreover, the $\mathrm{CD}$ spectrum shows an increased negative signal intensity around 205-208 $\mathrm{nm}$ for supramolecular structures formed at pH 3 (Fig. 6b), in comparison with pH 11 (Fig. 6a), suggesting that new regular secondary structures may have formed at lower $\mathrm{pH}$ during $\alpha$-La-Lys assembly. These results are in agreement with those reported by Diniz et al. (2014) for assembling of $\alpha$-La and glycomacropeptide, who observed a more intense negative peak for $\alpha$-La-GMP system at $\mathrm{pH} 3.5$ than at $\mathrm{pH} 6.5$ (when heated at $75^{\circ} \mathrm{C}$ ), and by Naqvi, Ahmad, Khan and Saleemuddin (2013) for $\beta$-lactoglobulin (prepared at $5 \mathrm{mg} \mathrm{mL}^{-1}$ ), who showed a higher negative molar ellipticity at pH 2.0 than at $\mathrm{pH} 7.0$ or 9.0 These findings suggest that acidic conditions may contribute to maintain the overall content of the secondary structures, or even favor their formation depending on the temperature and time of heating; conversely, the alkalinization of the protein solutions may cause the disruption of intermolecular interactions (e.g. hydrogen and disulfide bonds bonds), leading to expose of hydrophobic groups 
(Diniz et al., 2014).

The treatments confirmed that increased temperature cause substantial changes in the overall secondary structure pattern of the supramolecular complex at $\mathrm{pH} 11$; it is possible to observe a clear decrease in ellipticity intensity of $\alpha$-La-Lys structures, when the temperature increased from 25 to $75^{\circ} \mathrm{C}$, as well as an undefined peak around $208 \mathrm{~nm}$ (Fig. 6a), which may indicate that heat treatment promoted significant changes in $\alpha$-helices of $\alpha$-La and Lys (Jindal \& Naeem, 2013). This behavior was observed by Faizullin, Konnova, Haertle and Zuev (2013) for $\beta$-casein $\left(0.5 \mathrm{mg} \mathrm{mL}^{-1}\right.$ ) when heated from 10 to $60{ }^{\circ} \mathrm{C}$, and is in agreement with results reported by Zhang and Zhong (2012) who verified that increasing the heating temperature of bovine serum albumin $\left(0.6 \mathrm{mg} \mathrm{mL}^{-1}\right)$ and $\alpha$-La $\left(0.7 \mathrm{mg} \mathrm{mL}^{-1}\right)$ up to $85{ }^{\circ} \mathrm{C}$ reduce the intensity of the negative peaks in CD spectra, as a result of the decreased content of $\alpha$-helical structure obtained for both proteins, thus indicating that the secondary structure changed. These results suggest that $75{ }^{\circ} \mathrm{C}$ and $\mathrm{pH} 11$ are critical conditions to promote changes in $\alpha$-La and Lys secondary structures during protein assembling.

Regarding the effect of time exposure to heat, it was observed a shift of 2 and $13 \mathrm{~nm}$, for $\alpha$-La-Lys structures, at $208 \mathrm{~nm}$ for 15 and $35 \mathrm{~min}$ of heating, respectively, towards higher wavelengths (>215 nm), for $75^{\circ} \mathrm{C}$ at pH 11 (Fig. 6a). This suggests the presence of a progressively higher aggregate state within the heating time (i.e. from 15 to $35 \mathrm{~min}$ ), which is characteristic of $\beta$-sheet structures (i.e. $\beta$-sheets exhibit a broad negative band near $218 \mathrm{~nm}$ ) (Frydenberg, Hammershøj, Andersen, Greve, \& Wiking, 2015; Greenfield, 1999; Jindal \& Naeem, 2013). These results agree with the previously ones pertaining to DLS analysis, which showed an increase of size and PDI of supramolecular structures, prepared at $75{ }^{\circ} \mathrm{C}$, with heating time (i.e. from 15 to $35 \mathrm{~min}$ ) - Figs. $4 \mathrm{~b}$ and $5 \mathrm{~b}$.

Our results differed from those of Moro, Báez, Busti, Ballerini, and Delorenzi (2011), who studied $\beta$-lactoglobulin $\left(55 \mathrm{mg} \mathrm{mL}^{-1}\right)$ heated from 1 to $15 \mathrm{~min}$ at $85^{\circ} \mathrm{C}$, and those of Dave et al. (2013), for self-assembly of $\beta$-lactoglobulin $\left(10 \mathrm{mg} \mathrm{mL}^{-1}\right.$ ) heated from 0 to $60 \mathrm{~min}$ at $80^{\circ} \mathrm{C}$. These authors observed an increase in intensity of the $\mathrm{CD}$ spectrum for $\beta$-lactoglobulin, as well as a shift towards lower wavelengths within longer heating times. This difference was somehow expected since native $\beta$-lactoglobulin is rich in $\beta$-sheets (Qi et al., 1997; Uhrínová et al., 2000) displaying a CD spectrum with a negative peak at ca. $217 \mathrm{~nm}$ (characteristic of $\beta$-sheets). In these works the heat treatment changed the secondary structure of $\beta$-Lg leading to a decrease in the $\beta$-sheet content with a concomitant increase in $\alpha$-helix structure (i.e. shift towards shorter wavelengths).

On the other hand, major differences (in terms of ellipticity intensity and wavelength changes) in the CD spectra of $\alpha$-La-Lys supramolecular structures at $\mathrm{pH} 3$ (formed at $75^{\circ} \mathrm{C}$ ) cannot be observed within the time of heating (i.e. from 15 to $35 \mathrm{~min}$ ) Fig. 6b. These treatments showed that increasing temperature and heating time did not cause substantial changes in overall secondary structure pattern of the $\alpha$-La-Lys supramolecular structures at pH 3 (Jindal \& Naeem, 2013).

However, when said structures are formed at $25{ }^{\circ} \mathrm{C}$, a longer exposure to heat (i.e. $35 \mathrm{~min}$ ) showed lower molar ellipticity than heated for $15 \mathrm{~min}$ (Fig. 6b), thus suggesting that longer exposure cause prominent changes in protein secondary structure (Jindal \& Naeem, 2013).

The data showed that time of heating may have an effect on the content of secondary structures, but it is dependent on the heating temperature employed in the formation of protein nanostructures. This finding is consistent with the data obtained by DLS, which showed that heating time (from 15 to $35 \mathrm{~min}$ ) and $\mathrm{pH}$ (from 3 to 11) has a different impact upon size and PDI of supramolecular structures (Figs. $4 \mathrm{~b}$ and 5b, respectively), as function of the temperature (from 25 to $75^{\circ} \mathrm{C}$ ).

\subsection{Fluorescence spectroscopy}

In order to analyze the effect of $\mathrm{pH}$, temperature and time of heating upon the conformational and structural changes that could occur in the $\alpha$-La-Lys supramolecular structures, in relation to native $\alpha$-La and Lys proteins, intrinsic fluorescence of tryptophan (Trp) residues was measured. Trp fluorescence wavelength is known to be highly sensitive to the polarity of its surrounding environment, being a useful tool to monitor changes in proteins and to make inferences regarding local structure network and dynamics (Jindal \& Naeem, 2013; Vivian \& Callis, 2001). $\alpha$-La has four Trp residues in its primary structure at positions $26,60,104$ and 118, whereas Lys presents five at positions 28, 62, 63, 108 and 111 (Sgarbieri, 2005a). Hence, possible changes in the amino acids environment during the formations of supramolecular structures could be monitored through intrinsic fluorescence spectroscopy.

The emission spectrum of native $\alpha$-La and Lys, recorded between 290 and $450 \mathrm{~nm}$, was characterized by a maximum emission at $336 \mathrm{~nm}$ for both proteins (Fig. 7). These results were similar to those reported by Li, Zhang, and Ji (2014) for bovine serum albumin (0.133 $\mathrm{mg} \mathrm{mL}^{-1}$ ) and Zhang et al. (2014) for Lys $\left(0.133 \mathrm{mg} \mathrm{mL}^{-1}\right)$ who found a maximum emission at 338 and $335 \mathrm{~nm}$, respectively, when excited at $280 \mathrm{~nm}$.

The changes in the fluorescence intensity and wavelength of the maximum intrinsic fluorescence spectrum obtained for $\alpha$-La-Lys supramolecular structures when compared with native $\alpha$-La and Lys proteins were used to follow the structural modifications of the protein induced by $\mathrm{pH}$ ( 3 and 11 ), temperature $\left(25\right.$ and $75^{\circ} \mathrm{C}$ ) and time (15 and 35) of heating, as exhibited in Fig. 7.

As shown in Fig. 7a and b (for pH 11 and 3, respectively), native $\alpha$-La (used as control) displayed higher fluorescence intensity than $\alpha$-La-Lys structures, thus suggesting that interactions between these two molecules influence accessibility of Trp residues of $\alpha$-La in the protein system, which becomes less exposed to the solvent being placed in the nonpolar core of the system. On the other hand, it can be seen that $\alpha$-La-Lys nanostructures formed at $\mathrm{pH} 11$ presented a higher fluorescence intensity that native Lys (Fig. 7a), indicating that the Trp residues of Lys in the protein system becomes more polar and more exposed at this $\mathrm{pH}$ conditions (Diniz et al., 2014). These changes in the polarity may be related to the denaturation and aggregation phenomena induced by alterations of $\mathrm{pH}$, temperature and heating time during protein supramolecular structure formation (Ramos et al., 2014). A similar behavior was observed by Bourbon et al. (2015) during the fluorescence intensity analysis of lactoferrin-glycomacropeptide nanohydrogels relative to its proteins in native form.

Moreover, the emission spectrum of $\alpha$-La-Lys supramolecular structures formed at $\mathrm{pH} 11$ and $25^{\circ} \mathrm{C}$ shifted to shorter wavelengths i.e. a blue-shift to 334 and $332 \mathrm{~nm}$ for 15 and $35 \mathrm{~min}$ of heating, respectively was observed (when compared with the spectra of native $\alpha$-La and Lys) (Fig. 7a). These findings may indicate that the surrounding chemical environment of Trp residues became more apolar (Jindal \& Naeem, 2013; Taheri-Kafrani, Asgari-Mobarakeh, Bordbar, \& Haertlé, 2010; Taheri-Kafrani, Bordbar, Mousavi, \& Haertlé, 2008; Yue Zhang, Qi, Zheng, Li, \& Liu, 2009), suggesting that during the interaction between $\alpha$-La and Lys molecules, the Trp residues are less exposed to the solvent remaining buried deeper in the core of the $\alpha$-La-Lys system.

On the other hand, for protein supramolecular structures formed at the same $\mathrm{pH} 11$, but at $75{ }^{\circ} \mathrm{C}$, the wavelength of the emission spectrum was maintained, i.e. $336 \mathrm{~nm}$ for $15 \mathrm{~min}$ of heating, and shifted to higher wavelength, i.e. red-shifted to $338 \mathrm{~nm}$ for $35 \mathrm{~min}$ of heating, when compared with the spectra of 
a)

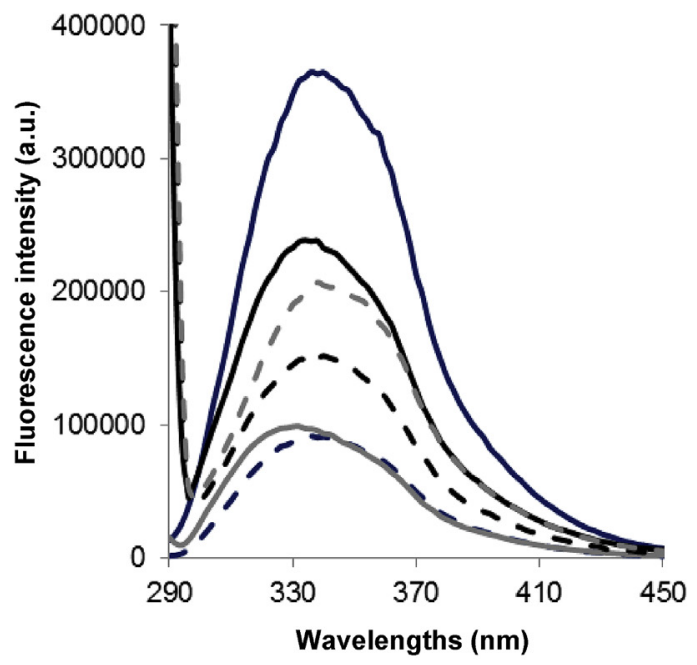

b)

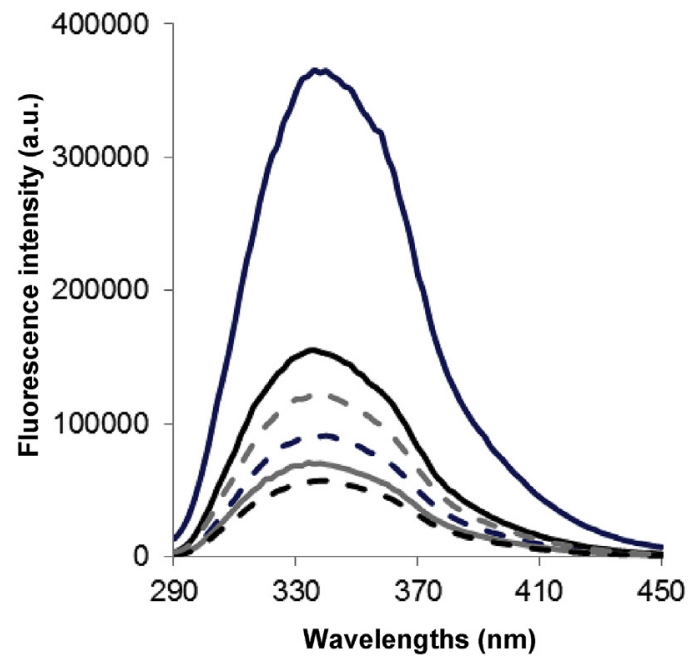

Fig. 7. Intrinsic fluorescence emission spectra of native $\alpha$-La (-) and Lys (- -) proteins (blue lines), and $\alpha$-La-Lys supramolecular structures (prepared at $2 \mathrm{mg} \mathrm{mL}^{-1}$, in a $\alpha$ La:Lys molar ratio of $0.546: 1$ ) obtained at $25{ }^{\circ} \mathrm{C}$ during $15(-)$ and $35(-)$ min and at $75{ }^{\circ} \mathrm{C}$ during 15 (- -) and 35 (- -) min, at (a) pH 11 and (b) pH 3 (For interpretation of the references to color in this figure legend, the reader is referred to the web version of this article).

native $\alpha$-La and Lys (Fig. 7a).

Comparing both systems when treated at 25 and $75{ }^{\circ} \mathrm{C}$ allows concluding that the increase in temperature slightly shift the maximum fluorescence emission intensity to higher wavelengths, thus indicating that Trp residues possibly became more polar - i.e. heating may have promoted changes in protein conformation around the Trp residues, thus rendering their neighborhood more polar (Zhang et al., 2014) and so more exposed to solvent (Jindal \& Naeem, 2013). Diniz et al. (2014) reported a similar behavior for $\alpha$ La-GMP structures when temperature was increased from 25 to $75{ }^{\circ} \mathrm{C}$.

In addition, $\alpha$-La-Lys nanostructures, treated at $25{ }^{\circ} \mathrm{C}$ for $15 \mathrm{~min}$ at both $\mathrm{pH}$ values, originated higher fluorescence emission intensity than conditions formed at the same pH values (Fig. 7a and b), so indicating that Trp residues of $\alpha$-La-Lys structures are more exposed to the solvent in the polar core of the system. In the case of supramolecular structures formed at $75{ }^{\circ} \mathrm{C}$, a higher fluorescence emission intensity was recorded at $35 \mathrm{~min}$ of heating for both $\mathrm{pH}$ values, when compared with that of samples heated for $15 \mathrm{~min}$ under similar conditions (Fig. 7a and b). This finding suggests that higher temperatures and shorter periods of heating expose less the Trp residues of $\alpha$-La-Lys structures to the solvent, being hidden in the core of the supramolecular structures formed.

Increasing the time of exposure to heat, at both $\mathrm{pH}$ values, led to an increase of fluorescence intensity of protein nanostructures when treated at $75{ }^{\circ} \mathrm{C}$; while the opposite was observed for $25^{\circ} \mathrm{C}$ (Fig. 7a and b). This difference in fluorescence intensity as a function of heating time and temperature reflects changes in the compactness of the protein molecule due to molecules unfolding, and changes in accessibility of Trp residues (Bourbon et al., 2015).

Comparison of the emission spectrum of supramolecular structures at both pH values allows seeing higher fluorescence intensity at $\mathrm{pH} 11$, indicating that the surrounding environment of Trp residues became more polar than at $\mathrm{pH} 3$. This may suggests that a less acidic $\mathrm{pH}$ solution provides a more suitable environment to enhance interactions between $\alpha$-La and Lys (Jindal \& Naeem, 2013). Naqvi et al. (2013) studied the intrinsic fluorescence of $\beta$-lactoglobulin and claimed that, at $\mathrm{pH} 9.0$, the protein showed higher fluorescence intensity than at pH 7.0, while Diniz et al. (2014) found higher fluorescence intensity at $\mathrm{pH} 6.5$ than at $\mathrm{pH} 3.5$, which agrees with our data. These results, together with those obtained by CD, confirmed that association between $\alpha$-La and Lys occurs under the conditions analyzed here, and that such association is affected by $\mathrm{pH}$, temperature and heating time.

\subsection{Morphology of $\alpha$-La-Lys nanostructures}

The morphology of $\alpha$-La-Lys structures prepared at $\mathrm{pH} 11$ and treated at $75{ }^{\circ} \mathrm{C}$ for $15 \mathrm{~min}$ was observed by TEM (Fig. 8), showing the presence of supramolecular structures with a spherical shape and at nanoscale level - nanoparticles. These images confirm formation of the structures by self-assembly of $\alpha$-La and Lys molecules, as well as the magnitude of size values obtained by DLS. The presence of some protein aggregates also confirms that particles' size distribution was not completely homogeneous, in agreement with the PDI values obtained.

\subsection{Stability of $\alpha$-La-Lys nanostructures}

Nanostructures may be exposed to a great variety of conditions when they are incorporated into products such as foods, cosmetics and pharmaceuticals (Bengoechea, Jones, Guerrero, \& McClements,

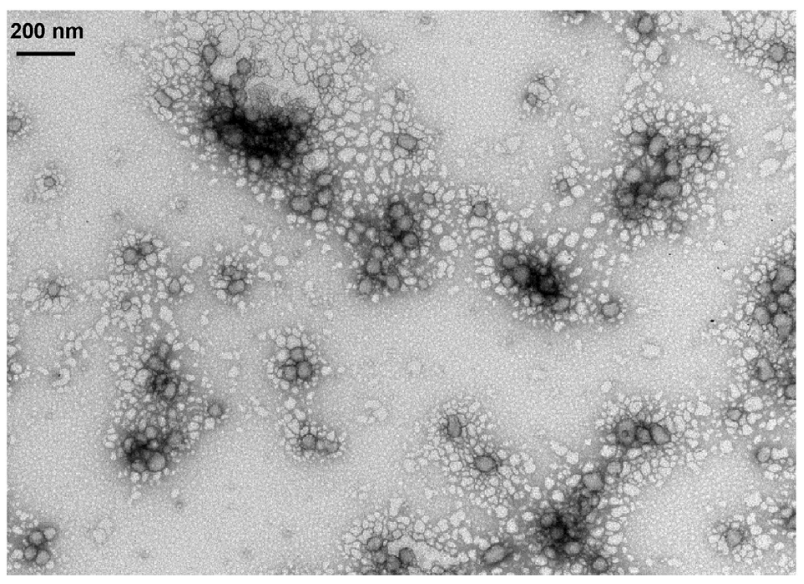

Fig. 8. TEM image of $\alpha$-La-Lys supramolecular structures (28 prepared at $2 \mathrm{mg} \mathrm{mL}^{-1}$, in a $\alpha$-La:Lys molar ratio of $0.546: 1)$ at $\mathrm{pH} 11$ and heating treatment of $75^{\circ} \mathrm{C}$ for $15 \mathrm{~min}$ (scale bar $=200 \mathrm{~nm}$, magnification $=60000 \times)$. 
2011a; Bengoechea et al., 2011b). It is therefore important to establish and assess the effect of various environmental conditions upon their stability and functional properties. In this section, the supramolecular structures produced at $\mathrm{pH} 11$, and treated at $75{ }^{\circ} \mathrm{C}$ for $15 \mathrm{~min}$, were selected based in their low size and PDI values, and the influence of temperature (i.e. 4 and $25^{\circ} \mathrm{C}$ ) upon their stability was evaluated by DLS during 150 days of storage (Fig. 9).

It was observed that $\alpha$-La-Lys supramolecular structures do not change their particle size or PDI $(p>0.05)$ significantly over 90

a)

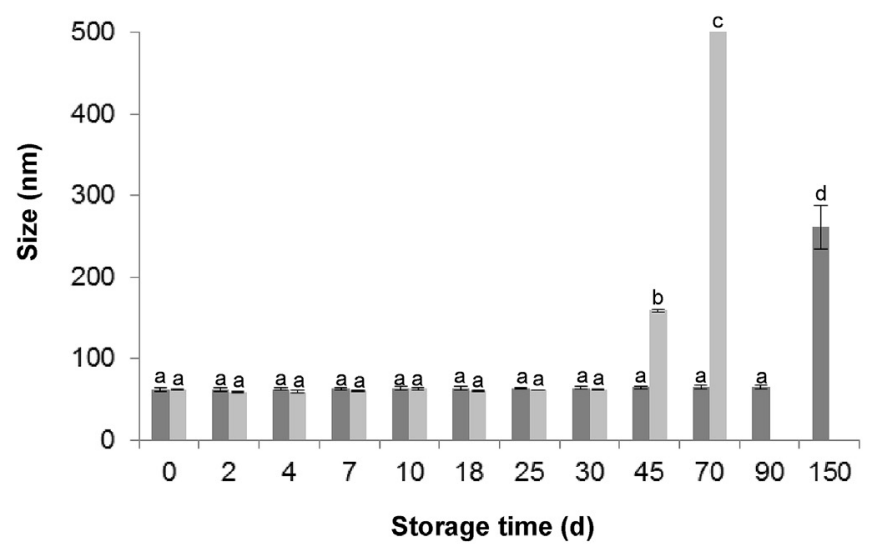

b)
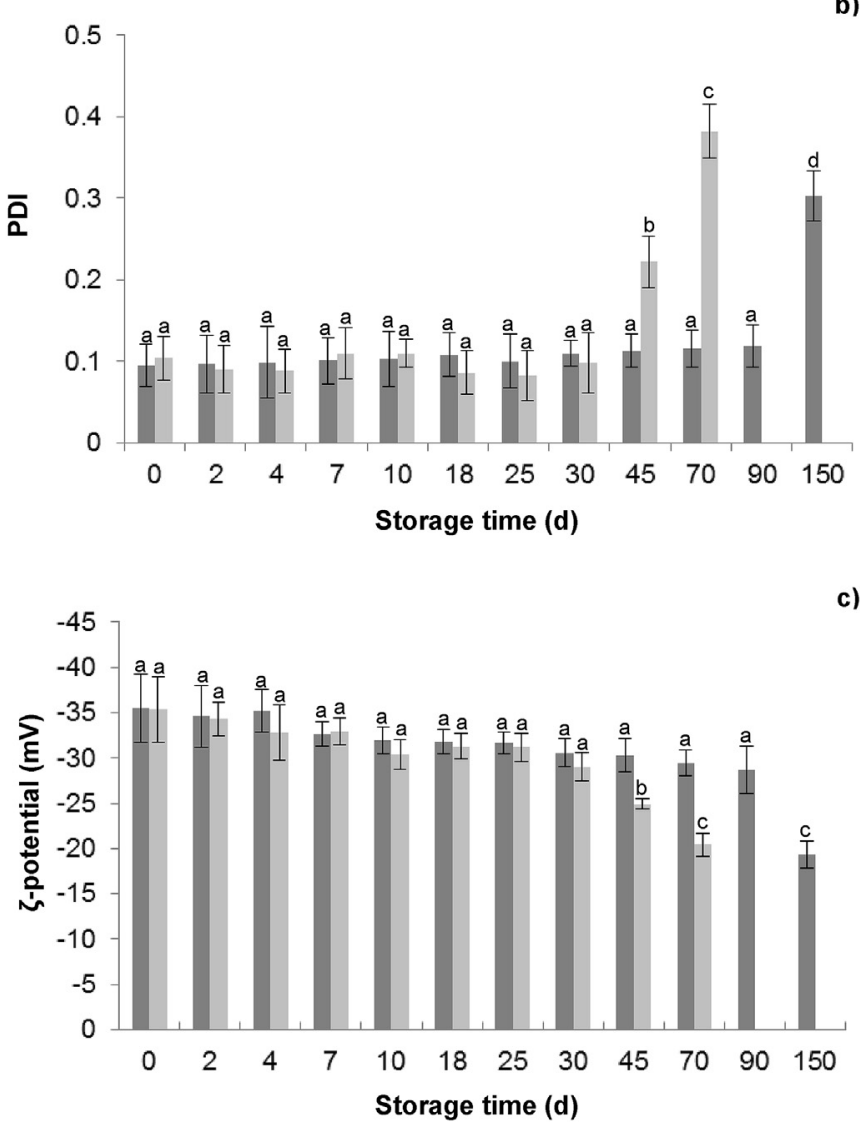

Fig. 9. Effect of temperature of storage at $4{ }^{\circ} \mathrm{C}(\square)$ and $25^{\circ} \mathrm{C}(\square)$ on the: a) hydrodynamic diameter size, b polydispersity index PDI and c $\zeta$-potential of $\alpha$-La-Lys supramolecular structures (prepared at $2 \mathrm{mg} \mathrm{mL}^{-1}$, in a $\alpha$-La:Lys molar ratio of $0.546: 1$ ) during 150 days of storage. Each data point is the average and the error bars show the standard deviation. Means labeled with the same letter do not statistically differ from each other $(p>0.05)$. days, when stored at refrigerated conditions (i.e. $4{ }^{\circ} \mathrm{C}$ ). In fact, size (ranging from $61.58 \pm 2.31$ to $65.37 \pm 2.91 \mathrm{~nm}$ ) and PDI (ranging from $0.095 \pm 0.027$ to $0.118 \pm 0.026$ ) remained relatively constant over that storage period (Fig. 9a and b). Moreover, size distribution was characterized by a single peak (results not shown), thus indicating that aggregation of particles in solution did not occur or was minimal; the cross-linking within the structure of the nanoparticles under these conditions appeared sufficient to suppress dissociation (Bourbon et al., 2015). These findings are in agreement with the $\zeta$-potential results, which showed values of $-28.71 \pm 2.57 \mathrm{mV}$ over 90 days (Fig. 9c). As reported before, structures are considered stable when their $\zeta$-potential values are higher than $+30 \mathrm{mV}$ or lower than $-30 \mathrm{mV}$ (Liu et al., 2012). After this period, the average size of supramolecular structures started to increase significantly $(p<0.05)$, reaching $261.0 \pm 27.11 \mathrm{~nm}$, with a corresponding PDI value of $0.303 \pm 0.03$; $\zeta$-potential values also changed significantly $(p<0.05)$, reaching $-19.30 \pm 1.51 \mathrm{mV}$ over 150 days of storage. This suggests that dissociation or aggregation phenomena may occur after 90 days, thus indicating a loss of colloidal stability. This hypothesis was experimentally confirmed by visual observation (results not shown) of a pronounced increase in turbidity occurring by 90 days of storage.

On the other hand, under room conditions (i.e. $25{ }^{\circ} \mathrm{C}$ ), the $\alpha$ La-Lys nanoparticles suspension only remained stable over 30 days of storage. During this period, statistically significant differences $(p>0.05)$ were not found in particle size and PDI values, while $\zeta$ potential values remained below $-30 \mathrm{mV}$ (Fig. $9 \mathrm{a}-\mathrm{c}$ ). After 30 days of storage, the particle size and PDI of $\alpha$-La-Lys structures significantly $(p<0.05)$ increased, reaching values of $159.2 \pm 1.904 \mathrm{~nm}$ and $0.222 \pm 0.032$, respectively, and the $\zeta$-potential also changed, reaching $-24.9 \pm 0.61 \mathrm{mV}$ by 45 days of storage. Afterwards, it was possible to observe the formation of two distinct phases. The progressive change in $\zeta$-potential values (i.e. $-30<\zeta$ potential $<+30 \mathrm{mV}$ ) may result in an increasingly stronger attraction between the surfaces of particles, leading to formation of larger aggregates and consequently phase separation (Nigen, Croguennec, et al., 2009a). Particle size values obtained after 70 days of storage (Fig. 9a and b) for $\alpha$-La-Lys supramolecular structures at $25{ }^{\circ} \mathrm{C}$ were far beyond the size that could be analyzed by DLS, so the aggregates were not further analyzed after this period.

The results obtained here are in agreement with the study conducted by (Bourbon et al., 2015) that showed that protein nanohydrogels (from self-assembly of lactoferrin and glycomacropeptide at $80^{\circ} \mathrm{C}$ during $20 \mathrm{~min}$ ) were stable for storage periods up to 5 months at $4{ }^{\circ} \mathrm{C}$.

\section{Conclusions}

Supramolecular structures can be formed by self-assembly of $\alpha$ La and Lys at different $\mathrm{pH}$ values and thermal (temperature and time of heating) conditions. $C D$ results showed changes in the secondary structure of protein supramolecular structures compared to their native proteins. Moreover, such structural changes appeared to be mainly governed by a higher contribution of Lys at $\mathrm{pH} 11$ and of $\alpha$-La at $\mathrm{pH}$ 3. Fluorescence analysis indicated that alkaline $\mathrm{pH}$ conditions provide a more suitable environment for interactions between $\alpha$-La and Lys, and thus towards formation of the supramolecular structures. The results of particle size distribution show that the proteins associated in different ways, depending on $\mathrm{pH}$, temperature and time of heating. Particle diameter ranged from nanometer-level at $\mathrm{pH} 3$ and 11 to micrometer-level at $\mathrm{pH}$ 7. At high $\mathrm{pH}$ (i.e. 11), high temperature $\left(75^{\circ} \mathrm{C}\right.$ ) and low time (15 min) of heating, supramolecular structures showed the lowest sizes and PDI values. Structures at these conditions are more stable when stored at refrigerated $\left(4^{\circ} \mathrm{C}\right)$ than at 
room $\left(25^{\circ} \mathrm{C}\right)$ conditions. The formation of supramolecular structures offers new opportunities to modify or improve functional properties of commercial products, such as foods and pharmaceuticals; and also as a smart vehicle for bioactive compound delivery. Heating and acidifying or alkalizing conditions can be optimized to control the properties of the proteins, and to improve their performance for tailor-made applications. Our results allowed a better knowledge of the factors that can help predict the behavior of protein associations in complex systems.

\section{Acknowledgments}

Adenilson A. Monteiro and Márcia R. Monteiro gratefully acknowledge their grants to $\mathrm{CNPq}$ and CAPES, and their support to FAPEMIG and CNPEM-LNBio (Centro Nacional de Pesquisa em Energia e Materiais-Laboratório Nacional de Biociências) both from Brazil. Oscar L. Ramos and Ricardo N. Pereira gratefully acknowledge their Post-Doctoral grants (SFRH/BPD/80766/2011 and SFRH/ BPD/81887/2011, respectively) to Fundação para a Ciência e a Tecnologia. The authors thank the FCT Strategic Project of UID/BIO/ 04469/2013 unit, COMPETE 2020 (POCI-01-0145-FEDER-006684), the project RECI/BBB-EBI/0179/2012 (FCOMP-01-0124-FEDER027462), and the project "BioInd - Biotechnology and Bioengineering for improved Industrial and Agro-Food processes", REF. NORTE-07-0124-FEDER-000028 Co-funded by the Programa Operacional Regional do Norte (ON.2 - O Novo Norte), QREN, FEDER.

\section{References}

Anema, S. G., \& Li, Y. M. (2003). Association of denatured whey proteins with casein micelles in heated reconstituted skim milk and its effect on casein micelle size. Journal of Dairy Research, 70(1), 73-83.

Augustin, M. A., \& Hemar, Y. (2009). Nano- and micro-structured assemblies for encapsulation of food ingredients. Chemical Society Reviews, 38(4), 902-912.

Augustin, M. A., \& Oliver, C. M. (2012). 1-An overview of the development and applications of nanoscale materials in the food industry. In Q. Huang (Ed.), Nanotechnology in the food, beverage and nutraceutical industries (pp. 3-39). Woodhead Publishing.

Bengoechea, C., Jones, O. G., Guerrero, A., \& McClements, D. J. (2011a). Formation and characterization of lactoferrin/pectin electrostatic complexes: Impact of composition, pH and thermal treatment. Food Hydrocolloids, 25(5), 1227-1232.

Bengoechea, C., Peinado, I., \& McClements, D. J. (2011b). Formation of protein nanoparticles by controlled heat treatment of lactoferrin: factors affecting particle characteristics. Food Hydrocolloids, 25(5), 1354-1360.

Blumlein, A., \& McManus, J. J. (2013). Reversible and non-reversible thermal denaturation of lysozyme with varying $\mathrm{pH}$ at low ionic strength. Biochimica et Biophysica Acta (BBA) - Proteins and Proteomics, 1834(10), 2064-2070.

Bobály, B., Tóth, E., Drahos, L., Zsila, F., Visy, J., Fekete, J., et al. (2014). Influence of acid-induced conformational variability on protein separation in reversed phase high performance liquid chromatography. Journal of Chromatography A, $1325,155-162$

Bourbon, A. I., Pinheiro, A. C., Carneiro-da-Cunha, M. G., Pereira, R. N., Cerqueira, M. A., \& Vicente, A. A. (2015). Development and characterization of lactoferrin-GMP nanohydrogels: evaluation of $\mathrm{pH}$, ionic strength and temperature effect. Food Hydrocolloids, 48(0), 292-300.

Cerqueira, M. A., Pinheiro, A. C., Silva, H. D., Ramos, P. E., Azevedo, M. A., FloresLópez, M. L., et al. (2014). Design of bio-nanosystems for oral delivery of functional compounds. Food Engineering Reviews, 6, 1-19.

Dave, A. C., Loveday, S. M., Anema, S. G., Loo, T. S., Norris, G. E., Jameson, G. B., et al (2013). $\beta$-Lactoglobulin self-assembly: structural changes in early stages and disulfide bonding in fibrils. Journal of Agricultural and Food Chemistry, 61(32), $7817-7828$.

Dickinson, E. (2003). Colloidal aggregation: mechanism and implications. In E. Dickinson, \& T. van Vliet (Eds.), Food colloids, biopolymers and materials (pp. 68-83). Cambridge: Royal Society of Chemistry.

Diniz, R. S., Coimbra, J. S. d. R., Teixeira, Á. V. N. d. C., da Costa, A. R., Santos, I. J. B., Bressan, G. C., et al. (2014). Production, characterization and foamability of $\alpha$ lactalbumin/glycomacropeptide supramolecular structures. Food Research International, 64, 157-165.

Dissanayake, M., \& Vasiljevic, T. (2009). Functional properties of whey proteins affected by heat treatment and hydrodynamic high-pressure shearing. Journal of Dairy Science, 92(4), 1387-1397.

Erabit, N., Flick, D., \& Alvarez, G. (2014). Formation of $\beta$-lactoglobulin aggregates during thermomechanical treatments under controlled shear and temperature conditions. Journal of Food Engineering, 120, 57-68.

Faizullin, D. A., Konnova, T. A., Haertle, T., \& Zuev, Y. F. (2013). Self-assembly and secondary structure of beta-casein. Russian Journal of Bioorganic Chemistry, 39(4), 366-372.

Frydenberg, R. P., Hammershøj, M., Andersen, U., Greve, M. T., \& Wiking, L. (2015). Protein denaturation of whey protein isolates (WPIs) induced by high intensity ultrasound during heat gelation. Food Chemistry, 192, 415-423.

Gill, P., Moghadam, T. T., \& Ranjbar, B. (2010). Differential scanning calorimetry techniques: applications in biology and nanoscience. Journal of Biomolecular Techniques : JBT, 21(4), 167-193.

Goers, J., Permyakov, S. E., Permyakov, E. A., Uversky, V. N., \& Fink, A. L. (2002). Conformational prerequisites for $\alpha$-lactalbumin fibrillation $\dagger$. Biochemistry, 41(41), 12546-12551.

Greenfield, N. J. (1999). Applications of circular dichroism in protein and peptide analysis. TrAC Trends in Analytical Chemistry, 18(4), 236-244.

Gunasekaran, S., Ko, S., \& Xiao, L. (2007). Use of whey proteins for encapsulation and controlled delivery applications. Journal of Food Engineering, 83(1), 31-40.

He, J.-S., Mu, T.-H., Guo, X., Zhu, S., Azuma, N., \& Kanno, C. (2013). Comparison of the gel-forming ability and gel properties of $\alpha$-lactalbumin, lysozyme and myoglobin in the presence of $\beta$-lactoglobulin under high pressure. Food $\mathrm{Hy}$ drocolloids, 33(2), 415-424.

Ipsen, R., Otte, J., \& Qvist, B. K. (2001). Molecular self-assembly of partially hydrolysed $\alpha$-lactalbumin resulting in strong gels with a novel microstructure. Journal of Dairy Research, 68(02), 277-286.

Israeli-Lev, G., \& Livney, Y. D. (2014). Self-assembly of hydrophobin and its coassembly with hydrophobic nutraceuticals in aqueous solutions: towards application as delivery systems. Food Hydrocolloids, 35(0), 28-35.

Iyer, L. K., \& Qasba, P. K. (1999). Molecular dynamics simulation of $\alpha$-lactalbumin and calcium binding c-type lysozyme. Protein Engineering, 12(2), 129-139.

Jindal, S., \& Naeem, A. (2013). Consequential secondary structure alterations and aggregation during prolonged casein glycation. Journal of Fluorescence, 23(3), 367-374.

Kaya-Celiker, H., \& Mallikarjunan, K. (2012). Better nutrients and therapeutics delivery in food through nanotechnology. Food Engineering Reviews, 4(2), 114-123.

Krebs, M. R. H., Bromley, E. H. C., Rogers, S. S., \& Donald, A. M. (2005). The mechanism of amyloid spherulite formation by bovine insulin. Biophysical Journal, 88(3), 2013-2021.

Lakowicz, J. R. (2006). Principles of fluorescence spectroscopy. USA: Springer.

Lehn, J.-M. (2007). From supramolecular chemistry towards constitutional dynamic chemistry and adaptive chemistry. Chemical Society Reviews, 36, 151-160.

Leonil, J., Henry, G., Jouanneau, D., Delage, M.-M., Forge, V., \& Putaux, J.-L. (2008). Kinetics of fibril formation of bovine $\kappa$-casein indicate a conformational rearrangement as a critical step in the process. Journal of Molecular Biology, 381(5), 1267-1280.

Liu, Y., Yang, J., Zhao, Z., Li, J., Zhang, R., \& Yao, F. (2012). Formation and characterization of natural polysaccharide hollow nanocapsules via template layer-bylayer self-assembly. Journal of Colloid and Interface Science, 379(1), 130-140.

Li, D., Zhang, T., \& Ji, B. (2014). Influences of pH, urea and metal ions on the interaction of sinomenine with Lysozyme by steady state fluorescence spectroscopy. Spectrochimica Acta Part A: Molecular and Biomolecular Spectroscopy, 130, 440-446.

Luding, Y., Shaochuan, S., Junxian, Y., \& Kejian, Y. (2011). Isolation of lysozyme from chicken egg white using polyacrylamide-based cation-exchange cryogel. Chinese Journal of Chemical Engineering, 19, 876-880.

Madureira, A. R., Pereira, C. I., Gomes, A. M. P., Pintado, M. E., \& Malcata, F. X. (2007). Bovine whey proteins - overview on their main biological properties. Food Research International, 40(10), 1197-1211.

McGuffey, M. K., Epting, K. L., Kelly, R. M., \& Foegeding, E. A. (2005). Denaturation and aggregation of three $\alpha$-lactalbumin preparations at neutral $\mathrm{pH}$. Journal of Agricultural and Food Chemistry, 53(8), 3182-3190.

McKenzie, H. A., \& White, F. H., Jr. (1991). Lysozyme and $\alpha$-lactalbumin: structure, function, and interrelationships. In C. B. Anfinsen, F. M. Richards, J. T. Edsall, \& D. S. Eisenberg (Eds.), Advances in protein chemistry (Vol. 41, pp. 173-315). Academic Press.

McSwiney, M., Singh, H., \& Campanella, O. H. (1994). Thermal aggregation and gelation of bovine $\beta$-lactoglobulin. Food Hydrocolloids, 8(5), 441-453.

Monteiro, A. A. (2014). Nanopartículas proteicas formadas por $\alpha$-lactoalbumina $e$ lisozima, e encapsulamento de quercetina e vitamina B2. Universidade Federal de Viçosa.

Moro, A., Báez, G. D., Busti, P. A., Ballerini, G. A., \& Delorenzi, N. J. (2011). Effects of heat-treated $\beta$-lactoglobulin and its aggregates on foaming properties. Food Hydrocolloids, 25(5), 1009-1015.

Naqvi, Z., Ahmad, E., Khan, R., \& Saleemuddin, M. (2013). Non-native States of Bovine Beta-Lactoglobulin Induced by Acetonitrile: pH-Dependent Unfolding of the Two Genetic Variants A and B. Cell Biochem Biophys, 66(1), 175-185.

Nicolai, T., \& Durand, D. (2013). Controlled food protein aggregation for new functionality. Current Opinion in Colloid \& Interface Science, 18(4), 249-256.

Nigen, M., Croguennec, T., \& Bouhallab, S. (2009a). Formation and stability of $\alpha-$ lactalbumin-lysozyme spherical particles: Involvement of electrostatic forces. Food Hydrocolloids, 23(2), 510-518.

Nigen, M., Croguennec, T., Renard, D., \& Bouhallab, S. (2007). Temperature affects the supramolecular structures resulting from $\alpha$-lactalbumin-lysozyme interaction. Biochemistry, 46(5), 1248-1255.

Nigen, M., Gaillard, C., Croguennec, T., Madec, M.-N., \& Bouhallab, S. (2010). Dynamic and supramolecular organisation of $\alpha$-lactalbumin/lysozyme 
microspheres: a microscopic study. Biophysical Chemistry, 146(1), 30-35.

Nigen, M., Le Tilly, V., Croguennec, T., Drouin-Kucma, D., \& Bouhallab, S. (2009b). Molecular interaction between apo or holo $\alpha$-lactalbumin and lysozyme: formation of heterodimers as assessed by fluorescence measurements. Biochimica et Biophysica Acta (BBA) - Proteins and Proteomics, 1794(4), 709-715.

Pereda, M., Ponce, A. G., Marcovich, N. E., Ruseckaite, R. A., \& Martucci, J. F. (2011) Chitosan-gelatin composites and bi-layer films with potential antimicrobial activity. Food Hydrocolloids, 25(5), 1372-1381.

Pinheiro, A. C., Bourbon, A. I., Cerqueira, M. A., Maricato, É., Nunes, C. Coimbra, M. A., et al. (2015). Chitosan/fucoidan multilayer nanocapsules as a vehicle for controlled release of bioactive compounds. Carbohydrate Polymers, $115,1-9$.

Qasba, P. K., Kumar, S., \& Brew, K. (1997). Molecular divergence of lysozymes and $\alpha$ lactalbumin. Critical Reviews in Biochemistry and Molecular Biology, 32(4), 255-306.

Qi, X. L., Holt, C., McNulty, D., Clarke, D. T., Brownlow, S., \& Jones, G. R. (1997). Effect of temperature on the secondary structure of beta-lactoglobulin at $\mathrm{pH} 6.7$, as determined by $\mathrm{CD}$ and IR spectroscopy: a test of the molten globule hypothesis. Biochemical Journal, 324(Pt 1), 341-346.

Ramos, O. L., Fernandes, J. C., Silva, S. I., Pintado, M. E., \& Malcata, F. X. (2012a). Edible films and coatings from whey proteins: a review on formulation, and on mechanical and bioactive properties. Critical Reviews in Food Science and Nutrition, 52(6), 533-552.

Ramos, O. L., Pereira, R. N., Martins, A., Rodrigues, R., Fuciños, C., Teixeira, J. A., et al. (2015). Design of whey protein nanostructures for incorporation and release of nutraceutical compounds in food. Critical Reviews in Food Science and Nutrition. 00-00, In Press, http://dx.doi.org/10.1080/10408398.2014.993749.

Ramos, O. L., Pereira, R. N., Rodrigues, R., Teixeira, J. A., Vicente, A. A., \& Malcata, F. X. (2014). Physical effects upon whey protein aggregation for nano-coating production. Food Research International, 66(0), 344-355.

Ramos, O. L., Pereira, J. O., Silva, S. I., Amorim, M. M., Fernandes, J. C., Lopes-daSilva, J. A., et al. (2012b). Effect of composition of commercial whey protein preparations upon gelation at various pH values. Food Research International, $48(2), 681-689$

Ryan, K. N., Zhong, Q., \& Foegeding, E. A. (2013). Use of whey protein soluble aggregates for thermal stability-a hypothesis paper. Journal of Food Science, 78(8), R1105-R1115.

Ryu, S. R., Czarnik-Matusewicz, B., Dukor, R. K., Nafie, L. A., \& Jung, Y. M. (2012). Analysis of the molten globule state of bovine $\alpha$-lactalbumin by using vibrational circular dichroism. Vibrational Spectroscopy, 60, 68-72.

Sanguansri, P., \& Augustin, M. A. (2006). Nanoscale materials development - a food industry perspective. Trends in Food Science \& Technology, 17(10), 547-556.
Sarkar, A., Goh, K. K. T., Singh, R. P., \& Singh, H. (2009). Behaviour of an oil-in-water emulsion stabilized by $\beta$-lactoglobulin in an in vitro gastric model. Food Hydrocolloids, 23(6), 1563-1569.

Sgarbieri, V. C. (2005a). Review: structural and physicochemical properties of milk proteins. Brazilian Journal of Food Technology, 8, 43-56.

Sgarbieri, V. C. (2005b). Review: structural and physicochemical properties of milk proteins. Brazilian Journal of Food Technologies, 8, 43-56.

Shih, P., \& Kirsch, J. F. (1995). Design and structural analysis of an engineered thermostable chicken lysozyme. Protein Science : A Publication of the Protein Society, 4(10), 2063-2072.

Shuguang, Z. (2003). Fabrication of novel biomaterials through molecular self-assembly. Nature Biotechnology, 21(10), 1171-1178.

Taheri-Kafrani, A. Asgari-Mobarakeh, E., Bordbar, A.-K, \& Haertlé, T, (2010). Structure-function relationship of $\beta$-lactoglobulin in the presence of dodecyltrimethyl ammonium bromide. Colloids and Surfaces B: Biointerfaces, 75(1) 268-274.

Taheri-Kafrani, A., Bordbar, A.-K., Mousavi, S. H.-A., \& Haertlé, T. (2008). B-lactoglobulin structure and retinol binding changes in presence of anionic and neutral detergents. Journal of Agricultural and Food Chemistry, 56(16) $7528-7534$.

Uhrínová, S., Smith, M. H., Jameson, G. B., Uhrín, D., Sawyer, L., \& Barlow, P. N. (2000). Structural changes accompanying ph-induced dissociation of the $\beta$ lactoglobulin dimer †,+. Biochemistry, 39(13), 3565-3574.

Viney, C. (2004). Self-assembly as a route to fibrous materials: concepts, opportunities and challenges. Current Opinion in Solid State and Materials Science, 8(2) 95-101.

Vinogradov, S. V., Bronich, T. K., \& Kabanov, A. V. (2002). Nanosized cationic hydrogels for drug delivery: preparation, properties and interactions with cells. Advanced Drug Delivery Reviews, 54(1), 135-147.

Vivian, J. T., \& Callis, P. R. (2001). Mechanisms of tryptophan fluorescence shifts in proteins. Biophysical Journal, 80(5), 2093-2109.

de Wit, J. N. (1998). Nutritional and functional characteristics of whey proteins in food products. Journal of Dairy Science, 81(3), 597-608.

Zhang Y. Oi, Z, Zheng. D., Li, C., \& Liu, Y. (2009). Interactions of chromium (iii) and chromium (vi) with bovine serum albumin studied by uv spectroscopy, circular dichroism, and fluorimetry. Biological Trace Element Research, 130(2), 172-184.

Zhang, M., Zheng, J., Ge, K., Zhang, H., Fang, B., Jiang, L., et al. (2014). Glycation of $\alpha$ lactalbumin with different size saccharides: effect on protein structure and antigenicity. International Dairy Journal, 34(2), 220-228.

Zhang, Y., \& Zhong, Q. (2012). Effects of thermal denaturation on binding between bixin and whey protein. Journal of Agricultural and Food Chemistry, 60(30), 7526-7531. 